Bu makalede; şehir planlama temel tasarım eğitiminde öğrenci kimliğinin bilesenlerinden olan kültürel birikimi ve formasyonunun, tasarım odaklı düşünce ve yaratıcı düşünce oluşumuyla ilişkili olduğu ve çeşitli faktörler bazında belirlenebileceğ savlanmaktadır. Makalenin amacı, söz konusu faktörleri bir örneklem bazında sorgulamak ve eleştirel bir bakış açısıyla değerlendirmektir. Süleyman Demirel Üniversitesi Şehir ve Bölge Planlama Bölümü temel tasarım dersinin iki müteakip yıl (2018-2019 ve 2019-2020) Güz döneminde anket uygulanmış ve inceleme yapılmıştır. İncelemede, anketten elde edilen kalitatif ve kantitatif veriler yanı sıra; Bahar ve Güz dönemi akademik performansları ve sınıf uygulama gözlemleri karşılaştırmalı analiz girdisi olarak kullanılmıștır. Tasarım odaklı düşünce ve yaratıcı düşünce oluşumu, tasarım muhakemesi ile eğitim metodolojisi, planı ve sürecine etki eden faktörler belirlenerek kategorize edilmiştir.

Araştırmanın evrenini, iki kümede (Grup I ve Grup II) toplam 121 denek olușturmaktadır. Araștırmadan elde edilen veriler üzerinde istatistiksel analiz olarak sayısal aktarım ve yüzde $(\%)$ hesabı yapılmıştır. Bulgulara göre, öğrencilerin eğitim formasyonları homojene yakın ve seçim usulü sayısal ağırlıklıdır. Analitik ve sistematik düşünme becerisi ve görsel sanatlara ilgisi olmadığını belirten ve oyun oynayan öğrenciler; tasarım odaklı düşünce, yaratıcı düşünce ve algı becerisi gelişiminde ve problemin gereği tasarı olușturmada başarısızdır. Babanın formasyonu da akademik performansta belirleyicidir. Sonuç olarak, öğrencinin kültürel birikimi ve formasyonu temel tasarım eğitim metodolojisi ve eğitim planı tasarımında dikkate alınması gereken bir girdi olarak değerlendirilmelidir.

Anahtar Kelimeler: Şehir Planlama, teme tasarım, tasarım odaklı düşünce, yaratıcı düşünce, Süleyman Demirel Üniversitesi.

\section{Sehir Planlama Temel Tasarm Eğitiminde Öğrenci Kültürel Birikimi ve Formasyonu Analizi: Süleyman Demirel Üniversitesi Örneği}

(D) Şirin Gülcen Eren

Süleyman Demirel Üniversitesi Mimarlık Fakültesi, Şehir ve Bölge Planlama Bölümü, Isparta, Türkiye

Başvuru tarihi/Received: 19.09.2020, Kabul tarihi/Final Acceptance: 05.10.2021

\section{Extended Abstract}

Basic design education is the basic training provided in the education of professionals whose job will be to design technically sound, liveable spaces and consequently society. This education, founded on knowledge and socio-cultural experience, is of vital importance. It forms the student's identity and is used at all stages of the profession. However, there are few academic studies that seek to determine the relationship between design education and the students' previous education, family backgrounds, fields of interest and past experience. In view of this gap in the literature, the present article considers the cultural knowledge and education of basic design students in conjunction with their academic performance and observations of their classes.

The article argues that, in basic design education in urban planning, there is a relationship between the students'cultural backgrounds and previous education and the development of their design-oriented thinking and creativity, and that this can be demonstrated with reference to various specific factors. The role of students'identities in the development of their design thinking and creative thinking, and in their academic performance, was examined for a given sample of students with the help of a questionnaire. The findings are discussed from a critical perspective.

The research was conducted in the basic design class of the Urban and Regional Planning Department of Süleyman Demirel University in the Fall semesters of two successive academic years (2018-2019 and 2019-2020). In addition to the quantitative and qualitative data obtained by means of the questionnaire, the academic performances of the students in the Spring and Fall semesters and observations made during the classes were used as inputs to the comparative analysis. The research was designed to evaluate the questionnaire and compare certain findings between academic performance at the end of the first and second semesters. It was supported by a review of the literature.

The research universe consisted of a total of 121 subjects divided into two groups (Group I and Group II). A statistical analysis was conducted of the data obtained by deriving the numbers and calculating the percentages. The students were found to have almost homogeneous educational backgrounds and to have been selected based on mathematics-weighted scores. The responses given to the questionnaire, the academic performances and the observations were identical or compatible for each of the two groups.

A number of factors were identified that affect the development of design thinking and creative thinking, design judgement and the educational methodology, plan and process, and these were adopted as parameters. These factors were categorised as follows: choice of department and the reasons for it; the students'cultural background; the education of the students and the education and professional profile of their parents, and the development of analytical and critical thinking.

The performance of students in the university entrance examination determines their academic success. For most of the students who were successful at school, the department was their department of choice. However, the fact that these students had chosen the department of their own volition and been accepted into it on the basis of their mathematics-weighted scores in the entrance examination did not mean that they had been able to develop creative thinking. The majority passed the class with a relatively poor performance. Students accepted from higher brackets have some difficulty in understanding or comprehending the subject. These low levels of perceptions are thought to stem from the orientation of the students, during their secondary education, towards a way of thinking that prioritises test-solving, and from dependency on mobile phones and games. The research does not provide sufficient data to support the view that individuals who receive pre-school education develop creative thinking more easily. The only clear finding is that the students lack imagination. The level of socio-cultural experience of the kind needed to ensure eye-hand-mind coordination in the development of design judgement and visual perception skills is low. This analysis also shows that the father's training is also a determinant of academic performance.

Students who stated that they did not possess analytical and systematic thinking skills and showing no interest in fine arts or playing games were found to be unsuccessful in developing design and creative thinking and perception skills and in creating designs responsive to the problem set. In consequence, during the course of the education provided, the majority of the students do not acquire the skills required to carry out the five design activities needed for the practice of design, and have no desire to develop a capacity for design judgement.

The conclusion was reached that the cultural and educational backgrounds of students are an input that needs to be taken into account when determining the methodology for basic design education and planning the courses.

Keywords: City planning, basic design, design thinking, creative thinking, Süleyman Demirel University. 


\section{Giriş}

Şehir planlama disiplin alanındaki temel tasarım konulu akademik araştırmalar genelde; temel tasarım kavramı ve tarihçesi, tasarım odaklı düşünce (Dorst, 2011), yaratıc1 düşünce (Denel, 1979), üniversite uygulamaları ve projeler (Sarıoğlu Erdoğdu, 2016), tasarım sorunsal1, temalar ve senaryolar, çerçeveleme (Dorst, 2011; 2015; 2018), temel tasarım ve Gestalt ilkeleri (Günay, 2007), görsel alg1 (Hunt, 1987; Tekel vd., 2016), algının oluşum ve gelişimine dair olası yöntemler (Tekel vd., 2015), eğitim ve ders planları (Kayın, 2000; Sarıoğlu Erdoğdu, 2016) ile tasarın niteliği konularına yoğunlaşmaktadır.

Araştırmalar, öğrencinin (tasarımcı adaylartnin) kimliğini oluşturan kültürel birikimi ve formasyonunun, tasarım odaklı düşünce ve yaratıcı düşünce oluşumuyla ilişkisini belirlemede eksiktir. Söz konusu ilişkiyi belirleyen faktörlerin parametreye çevrilerek değerlendirilmesine dair tespit veya yöntem önermesi içeren araştırmalar da kısıtlıdır. Sadece Tekel vd. (2016) tarafindan öğrencilerin kişisel ilgi ve deneyimlerinin görsel algı becerilerinin gelişim düzeyi ile ilişkisi normatif olarak sorgulanmış; öğrenci ilgi ve deneyiminin görsel alg1 becerisinin gelişimine katkı sağladığı belirlenmiştir. Farklı üniversitelerdeki temel tasarım eğitimlerinin program, plan ve metodolojilerinin öğrencinin kültürel birikimi ve formasyonuna bağlı değişkenliğine dair bir çalışma ise bulunmamaktadır.

Öğrencinin formasyonu; aile yapısı, ilgi alanları ve geçmiş deneyiminin tasarım eğitimiyle olan ilişkisinin tespitine dair belirtilen eksiklik, eğitim programlarının kurgulanması yanı sıra yeniden tasarımı sonrası uygulanabilirliğini ve kıyaslama zeminini ortadan kaldırmaktadır. Bu bağlamda makaleye, temel tasarım öğrencilerinin kültürel birikimi ve formasyonu, akademik performansları ve sınıf gözlemleri konu edilmiştir. Makalede, öğrencilerin kimliğinin tasarım odaklı düşünce ve yaratıcı düşünce oluşumuyla iliş̧ili olduğu ve çeşitli faktörler bazında belirlenebileceği savlanmaktadır. Makalenin amacı, kimliğin akademik performansla ilişkisini bir örneklem bazında belirlemek; ilişkiyi oluşturan faktörleri kategorize etmek ve eleştirel bir bakış açısıyla değerlendirmektir.

Makalede, öğrencinin öğrenme ortamındaki fiziki (malzeme, dijital veya karma) kaynakları kullanımının kolaylaştırılması; program, plan ve metodolojilere uyumu ve alg1 düzeyinin arttırılmasına yönelik yöntemlerin etkin ve bilinçli uygulanmasına katk1 yapılması hedeflenmektedir. Makalenin ikincil hedefi, öğrencinin kültürel birikimi ve formasyonu konusunda farkındalık yaratılması suretiyle; eğitmene ve eğitim metodolojisine yeni bir bakış açısı sunmaktır. Araştırmanın temel tasarım eğitim program ve planlarının tasarımına dair önermede bulunması da öngörülmektedir.

Araştırma, Süleyman Demirel Üniversitesi (SDÜ) Mimarlık Fakültesi Şehir Planlama Bölümü bazında yapılmıştır. Bölümün temel tasarım eğitim yaklaşımı; planlama ızgarası, oran sistemleri, şemalar benzeri kuralları içeren estetik odaklı Kanonik Eğitim (Broadbent ve Ward, 1969)'dir. Eğitimin içeriği, mimarlık pedagojisinde var olan klasik tasarım eğitim alıştırmaları (uygulamaları/temrin) ile teknoloji kullanımı içeren alıştırmalardan oluşan melez (hibrit) bir eğitimdir. Melez tasarım eğitimi, belirli bir programa bağlı veya anlık değişen bir içerikte, klasik öğreti ve bilgisayar teknolojilerinin kullanımı veya klasik öğreti ve bilgisayar destekli tasarım öğretisi bütünüdür. Eğitim planı, diğer üniversitelerle ortak alıştırmalar içermektedir.

Eğitim, çevrimiçi (uzaktan eğitim) de yapılabilmektedir. Covid-19 pandemisi nedeniyle, 2020 Mart tarihinde çevrimiçi eğitime kısmi alıştırma değişikliklikleriyle geçilmiştir. 2021 yılı Güz döneminde yüz yüze klasik eğitim yeniden başlamıştır.

Planlama Projesi I ve II (PLN 101-102) dersleri, bölümün iki dönemde verilen birinci sinif temel tasarım dersleridir. Derste; Denel (1979), Günay (2007), Sarıoğlu Erdoğdu (2016)'nunda vurgu yaptığı, klasik tasarım eğitiminin problem çözme eyleminin ve estetiği yaratmanın temel aracı olan Bauhus Okulu'nun temel tasarım ve Gestalt tasarım ilkeleri öğretilmektedir. Kent Kuramı, Mekân Kuramı ve Oyun Kuramı çerçevesinde eğitim metodu belirlenmekte ve 
planı hazırlanmaktadır. Yaparak öğrenme alıştırmaları ve grup ve saha çalışmaları yapılmaktadır. Dersin değerlendirme yöntemi; teslimler, sınıf eskiz çalışmaları, kısa sinavlar, kritikler ve juriler şeklindedir.

Güz döneminde verilen Planlama Projesi I dersinde yaratıcilık ve tasarım kavramları temelinde; nokta, çizgi, referans çerçevesi, tipografi, piktografi, şekil zemin ilişkisi, temel tasarım ilkeleri, Gestalt ilkeleri, renk, doku, soyutlama, tasarım geometrisi, oran-orant, modül-modülasyon, yüzey ve hacim konuları verilmekte; iki boyutlu alıştırmalar yapılmakta ve hayalgücü geliştirilmektedir. Planlama Projesi II Bahar dönemi dersinde ise, üç boyutlu hacim-kütle alıştırmalarından sonra mekâna ve kente geçilmektedir. Mekân (fiziksel belirleyiciler, kademelenme, topografya, insan ölçeği), insan eylemleri, barınma birimi, insan-mekân ilişkisi, kentsel okunabilirlik, kentsel rota/ omurga, konut tipolojileri ve dokuları ile konut yaşam çevresi çalışma konularıdır. Makalenin giriş bölümünün ardından, ilk olarak, çalışmanın kavramsal çerçevesi aktarılmakta; müteakip kısımda çalışma yöntemi açılanmaktadır. Dördüncü bölümde anket çalışmasının bulguları sunulmakta; bulguların değerlendirmesi ise sonuç bölümünde yer almaktadır.

\section{Kavramsal Çerçeve}

Tasarım, öğretilebilen, eğitimle geliştirilebilen veya ortaya çıkartılabilen bir beceridir (Günay, 2007; Hunt, 1987; Sarıoğlu Erdoğdu, 2016). Tasarım öğretisinin edinimi, tasarım odaklı düşünce ((Design thinking) Dorst, 2011; 2015) gelişimi ve yaratıcı düşünce ((Creative thinking) Denel, 1981; Doyle, 2019; Kuloğlu, 2000; Özcan vd., 2003; Tekel vd., 2016) eğitimi ile mümkündür. Günay (2007), tasarım süreçlerinde her iki düşünceyi geliştirerek ihtisaslaşan öğrencinin çevreyi ve mekân algısını oluşturması ve eleștirel olmayı öğrenmesi için, tasarım eğitimiyle bilgi ve beceri ve sanat sahibi olması gereğine vurgu yapmaktadır.

Tasarım odaklı düşünmenin özü; karmaş1k problemin çözümüne yoğunlaşma, çözüm için yenilikçi yaklaşımlarla farklı bir bakış açısı sunumu ve sunum yöntemi- nin arayışına dairdir (Dorst, 2011). Tasarım odaklı düşünce genel olarak, öğrencinin ve tasarımcının çözüm geliştirme becerilerine odaklanan (Dorst, 2015); çeşitli yöntemler içeren bir paradigmadır (Dorst, 2011). Yaratıcı düşünme becerisi ise, geliştirilerek tercüme edilebilir akıl süreçleridir. Yaratıcı düşünce, edinilmesi gereken bir fikri veya nesneyi yaratma olgusundan hareket ettiğinden; düşüncenin sistematiği, hem süreç hem beceri olarak tanımlanabilmektedir (Denel, 1981).

Her iki düşünce, öznesi insan ve mekân olan kanonik eğitim programlarında temel tasarım eğitimiyle disipline edilir. Sanat ve mimarinin temelini oluşturan temel tasarım eğitimi, yürütücünün, varlık bilimi açısından kişisel konumuna (bilgi, gerçek ve meşruiyete karşı tavrı) ve dünyayı kavramsallaştırma ve analiz etme becerisine göre, bilgi temsillerini bilinçli olarak seçtiği bir süreçte işlenir (Sarıoğlu Erdoğdu, 2016).

Kentsel biçimin estetik kompozisyonu, öğrencinin görsel alg1 ve becerilerinin temel tasarım eğitimiyle geliştirilmesini gerektirir. Bu durumun esas gerekçesi, kentin biçiminin iki ve üç boyutlu bir komposizyon problemi olmasıdır (Günay, 2007). Bu nedenle, Mimarlık ve Şehir ve Bölge Planlama bölümlerinde temel tasarım dersi zorunlu temel derstir. Mimarlık ve Sehir Planlama tasarım öğrencileri ise, merakları olmasa da, yaratıcı düşünceyi öğrenme yükümlülüğü olan bireylerdir. Üniversitelerin ilk yıl bir veya iki dönemde uygulanan temel tasarım eğitimlerinde ortak kabul görmüş standart bir uygulama ise, yoktur.

Tasarım eğitiminin amacı; görmeye ve düşünmeye yönelik yöntem ve teknikleri kavratarak, öğrencinin görsel ve psikolojik boyutu olan görsel dili öğrenmesidir. Diğer bir amaç; yaratıcılığı, bir değere sahip sanat objesi (Atmaca, 2014) veya ürün (imaj, nesne, hizmet veya sistemin), plan veya projenin üretimi faaliyetinde kullanma becerisini geliştirmektir. Şehir planlama disiplin alanı akademik çalışmaları (Bayraktar vd., 2012; Özcan vd., 2003; Tekel vd., 2015; 2016); tasarım odaklı düşünme ve görsel algılama becerisinin temel tasarım eğitimiyle geliştiğini ispat etmektedir. 
Eğitimlerde öğrencinin yanal düşünme şekli ve görsel algısının (Baytin, 2000; Denel, 1979; Grigg ve Lewis, 2019; Kuloğlu, 2000; Tekel $v d ., 2016)$ gelişimi yanı sıra; estetik duyumlarının (Arkun vd., 2000) oluşumu ve belirli çalışma şekillerinin gelişimi (Dorst, 2011) beklenen sonuçlardır. Üretimde; alan bilgisi, teknik çizim ve sunum becerilerinin kullanımı yoluyla düşüncenin yansıtılması istenilmektedir.

Öğrenciler, temel tasarım eğitiminin belirtilen içeriğini bilmeden tercih yapmaktadır. Bölümü, şehir planlama bölümü olduğu için tercih eden; sadece puanı tuttuğu için seçen veya tasarımla ilişkili olduğundan tercih yapan öğrenciler vardır. Öğrencilerin bazılarının ilk tercihi mimarlık bölümüdür. Denel (1979)'e göre, mimarlık bölümünün tercih nedeni, sosyal baskı ve meslek hakkındaki yanlış kanılarıdır. Eğitimde nadir olarak ne istediğinin ve neyin içine gireceğinin farkında olan öğrenciyle karşılaşıldığını da eklemektedir. Bu nedenle, eğitmen açısından biraz daha kontrollü olan tasarım eğitimi, öğrenci için zordur.

Çoktan seçmeli eğitim sisteminden gelen öğrenciler; teknik çizim aletleriyle ölçme-hesap yapılması, göz-el-zihin arasındaki bağın kurulması (Kuloğlu, 2000; Sarıoğlu Erdoğdu, 2016), sezgisel öğretme metodları kullanılması, kritik alma süreci ve juri yöntemiyle değerlendirilmesi ve alıștırma sayısının fazla olması nedeniyle zorlanmaktadır (Sarıoğlu Erdoğdu, 2016; Çubukçu ve Gökçen Dündar, 2007; Günay, 2007). Günay (2007:93) da, stüdyo ve temel tasarım dersinin yazılı metin ve formüllerle çalışmaya alışkın öğrencilere; çizgiler, yüzeyler, hacimler, renkler ve dokulardan oluşan soyut dünyanın yabancı geldiğini belirtmektedir. Kavas vd. (2016) bu durumu, öğrencinin doğrunun mutlak ve tek olarak kabul edildiği eğitim anlayışından, birden fazla çözümün doğruya ulaşmasını içeren yeni düşünceye uyumdaki zorlanma olarak tanımlamaktadır.

Değişik sosyal yapı, etnik köken, eğitim sistemi, kültür ve coğrafyadan gelen öğrencilere farklı formasyonlara sahip eğitmenlerce verilen eğitimlerde, ortak ve belirli bir seviyede tasarım odaklı düşünce ve yaratıcı düşünce oluşturmak da zorlu bir süreçtir. Eğitim sürecinde; öğrencinin zorlanma durumuna göre, belirli aşamalarda, değişik tür ve ölçekte alıştırmalar verilmektedir. Eğitmenler, ürünü ve bireyin yaratıcı düşüncesini geliştirecek şekilde bir değerlendirme yapmaktadır. Ayrıca, olması gereken seviyede bir gelişmenin sağlanabilmesi için, sınıf genelinin algılamada zorlandığı önceki konuların farklı uygulamalarına geri dönülmektedir (Reculer pour mieux sauter (Gouwy, 2013)).

Tasarım eğitimine etki eden çeşitli bileşenler vardır: Görsel alg1 ve düşünme becerileri, geçmiş deneyimler, fiziki mekân şartları, eğitim planı ve metodolojisi, eğitmen niteliği. Diğer bileşenler; eğitim metodolojisindeki yenilikler, farklılaşan yaklaşımlar, seyahatler, sergiler, hobiler, ilgi alanları ve benzeri etkinlikler yoluyla sosyalleşen (Tekel vd., 2016) öğrencinin kültürel birikimi, teknoloji kullanımı ve teknolojik yeniliklere uyumu olarak sıralanabilir. Bileşenlerin etkileşim ve varlık düzeyi ve ölçeği, karmaşık ve değişkendir; ve sonuç ürünün kalitesini belirlemektedir.

Öğrencinin eğitim seviyesi ve sosyo-kültürel yapısı önemlidir. Çünki, bu yapı üzerine tasarım eğitimiyle, bir bilgi ve enformasyon edinimi sağlanmaktadır. Algı yaratımı ve analiz-sentez yeteneği kazandırılması yoluyla ise, yaratıcılık becerisi geliştirilmektedir. Bilgi, beceri ve yetkinlik düzeyinde karşıllaşılan zorluklar, metodolojik hatalar ve seçilen alternatifin geliştirilmesinde oluşan kopukluk, öğrencinin bu birikimi yanı sıra, eğitim ve mesleki yaşamını etkilemektedir (Ayıran, 1985; Kavas $v d ., 2016)$.

Öğrencinin tasarım muhakemesi oluşturması (problemi anlama ve çözmesi, hayalgücünü ve ilkeleri kullanması, matematik ve geometriye hâkimiyeti), kültürel birikimi ve formasyonuyla ilişkilidir. Sausmarez (1992) de, muhakeme ve yaratıcı faaliyete ilişkin ve eğitime dair fikirlerde değişikliğin nedeni olan faktörler arasında kişiliği saymakta, estetiğe dair kararda kişiliğin tamamının müdahil olduğunu ve bireysel anlatımın temelini kişisel tercihlerin oluşturduğunu belirtmektedir. 
Özcan vd. (2003:20), Erkman (1982)'dan alıntılayarak, kişilik özelliklerinin algılama sürecine öznel bir nitelik kattığını ve ait olunan sosyal grupların etkin rol oynadğını betimlemektedir. Ayrıca algılamanın, kișilere göre değiștiğini savlamaktadır (Özcan vd., 2003).

Görsel sanatlara ilgi, öğrencinin kişiliğini şekillendiren bir girdidir. Tekel vd. (2016), öğrencilerin görsel sanatlara ilişkin uygulamalı deneyimlerini; kurslara katılım; görsel sanatlara ilişkin ilgi düzeylerini ise, etkinliklere gitmek şeklinde tanımlamaktadır. Tekel vd. (2016)'nin anket yöntemiyle yaptıkları araştırma sonucunda, temel tasarım eğitimi öncesinde görsel sanatlara ilgisi ve deneyimi olan öğrencilerin görsel alg1 ve ifade gelişim süreçlerinin daha olumlu olduğu ve eğitimle görsel algının geliştirilebildiği belirlenmiştir.

Bu bağlamda, temel tasarım eğitimi, öğrenci kişiliği ve formasyonu temelinde çok boyutlu, çok taraflı ve çok aktörlü etkileşimi olan disiplinler arası (Dorst, 2018; Hunt, 1987; Ülger, 2015; Ylldrrum, 2019) bir görsel okuryazarlık eğitimi olarak da tanımlanabilir. Görsel elemanları ve dili kullanarak kişisel anlatım yoluyla ürün yaratmak ve görsel alg1 ve düşünceyi geliştirmek görsel okuryazarlı̆̆ın gelişmesinde rol oynamaktadır (Greh, 1984). Temel görsel çalışmalar algısal bilinci arttırdığından (Arnheim, 1965; Wolff, 1965), alıştırmaların kişiliği şekillendirdiği de düşünülebilir.

Öğrencinin; süreçte, sorunu algılaması, öğrendiğini planlaması, anlatması, değerlendirmesi (Grigg ve Lewis, 2019), motivasyonunu yüksek tutması, yapıcı eleştirel düşüncesini geliştirmesi ve iletişime ve işbirliğine açık olması (Aydın, 2001; Çağlar, 2002) beklenmektedir. Görsel dilin gelişmesinde; yeni ve farklı olanı öngörmek için, öğrenmeye hazır, istekli olmalı ve eğitim sonrasında becerileri kullanabilmelidir (Grigg ve Lewis, 2019:3). Söz konusu yetilerinden en önemlisi alg1 ve anlama yetisidir. Baytin (2000:50), mimarlık temel tasarım öğrencilerine uygulanan bir ankette, öğrencilerin $\% 51$ 'inin dersi biraz anladığı veya anlamada zorlandığını belirlemiștir.

Akademik başarı ve öğrenme konusunda
Avnet vd. (2019)'ne göre, ebeveynlerin eğitim düzeyi ve meslek profili öğrencinin başarısında ve okula uyumunda etkilidir. Butcher vd. (2006) benzer bir tespiti öğrencinin formasyonuyla ilgili olarak yapmaktadır. Eğitim durumu-başarı ilişkisi konusunda genelde üniversite öncesi eğitim seviyelerinde ebeveyn müdahalesi, eğitim düzeyi ve engeller konularında akademik çalışmalar mevcuttur (Desforges ve Abuchaar, 2003; Avnet vd., 2019). Nelson (2009)'un üniversite eğitiminde ebeveyn eğitimi-öğrencinin başarısı ilişsisine dair çalışmasında; babanın eğitimi (annenin değil), öğrencinin performansı ile pozitif bir korelasyon kurmaktadır.

Lawson ve Dorst (2009), tasarım pratiğinde beş tasarım faaliyet grubu belirlemiştir: Formüle etme, sunma, hareket ettirme, değerlendirme ve idare etme. Usta vd. (2000), tasarlama etkinliğini tasarımcının zihninde sürüp giden işlemler bütünü olarak tanımlamakta ve bu olgunun düşünme olduğunu belirtmektedir. Dorst (2011) ise, tasarımın birçok çeşit düşünce şeklinin karışımı olduğunu ve tüme varım ve problem çözme üzerine yapılandığını belirtmektedir. Eğitim sürecinde öğrenci, çıkarımsanan bir değere ulaşma yöntemine ilişkin önermede bulunmakta ve belirlenen bir çerçevede bir değeri elde etmek için stratejiler geliştirmektedir. Bu olgu, tasarım muhakamesidir (Dorst, 2011). Muhakemenin oluşumu, analitik ve eleştirel düşüncenin de gelişimi anlamındadır.

Analitik ve eleştirel düşünce gelişimiyle ilişkili faktörler; hayalgücü, bilinç, sistematik düşünce, matematiksel ve istatistiksel hesaplara ve sayısal bulmacalara ilgi, çözüm için formül üretebilme olarak belirlenmiştir. Öğrencinin kimliği üzerine eklemlenen düşüncelerin gelişimi, zamana, mekâna ve problem içeriğine göre değișebilmektedir. Tasarım gelișme seviyesine göre, eğitmenlerce öğrenci değerlendirilmektedir. Aslında asıl değerlendirilen, tasarım muhakemesinin gelișim düzeyidir Günay (2007)'a göre, dengeli bir kompozisyon, deneyimli bir gözü gerektiren bir değer muhakemesidir. Bu nedenle eğitim sürecinde; eğitmenlerce, sürekli olarak 
gözün eğitiminin gereği vurgulanmaktadır. Öğrencinin alıştırmalarla yetinmeyerek, kendisini görsel sanatları takip ederek ve hobiler geliştirerek yetiştirmesi gerekmektedir. Tekel vd. (2016, Bknz. Grafik 2), öğrencinin görsel sanatlara ilişkin ilgi düzeyi arttıkça temel tasarım çalışmalarındaki başarı oranının yükseldiğini ve uygulamalı deneyimleri olanların sınıfın genel başarı ortalamasının üzerinde olduğunu belirtmektedir.

Mimarlık ve planlama okullarına sayısal puan ile öğrenci alınmasının nedeni; en baştan öğrencinin belirtilen puanlama içerik ve sistematiğiyle, matematik ve geometri bilgisi yanı sıra, belirtilen faaliyetleri yapabilme becerisine sahip olduğu varsayımıdır. Dahası, öğrencilerin sorun çözme kapasitesi ile analitik düşünce ve eleştirel düşünce kabiliyeti gelişebilecektir. Tam tersi de geçerlidir. Silver (1981), görsel alg1 eğitiminin öğrencilerin matematik performansını arttırdığını ispat etmiştir.

Öğrencilerin formasyonunun tasarım odak1 düşünce ve yaratıcı düşünce oluşumuyla olan formel ilişkisi anaokulunda başlamaktadır. Anaokulu eğitimi, bireyin yaratıcılık ve hayal gücü gelişiminde ailenin ilgisiyle birlikte önemli bir rol oynamaktadır (Craft, 2002; Michalopoulou, 2014; Al-sagrat ve Abu As'ad, 2015). Eğitim sırasındaki hayalgücü eksikli$\breve{g} i$, anne ve aile eğitimi yanı sıra, anaokulu eğitimi boyunca öğrencinin hayal kurmadı$\breve{g}_{1}$ anlamına gelmektedir (Er Biylklı ve Gülen, 2018; Çetin, 2012).

Eğitim içeriği, felsefesi ve metodolojisi de düşüncenin ve becerinin gelişiminde önemlidir. Bireye okul öncesi eğitimden itibaren, otantik öğrenmeyi deneyebileceği imkânlar sunulmalıdır (SSahin ve Dostoğlu, 2016; Toğrul, 2007). Otantik öğrenme, uygulamalı bir yaklaşımdır ve öğrencilerin gerçek dünya bağlamında, yeni bilgileri uygulamalarına olanak sağlayan, soru sorarak ve seçim yaparak değerlendirme yapabildiği öğretim tekniklerini içermektedir. Ayrıca, beceriyi keşfetmek ve geliştirmek için, bireyin uygun ortamda büyümesi veya büyütülmüş olması gerekmektedir.

Eğitimde cep telefonu (m-learning) ve teknoloji kullanımı, çevrimiçi eğitim ve dijital tasarım eğitimi farklı kavram ve metodolojik yaklaşımlardır. Günümüzde bireyin telefonuna ve sanal dünyaya bağımlılığ yaygın (bknz. Lahiry vd., 2019) olup, kullanımı bireyin, fiziki, psikolojik, sosyal ve eğitimsel iyiliğine zarar vermekte ve sağlik sorunlarına yol açmaktadır (Darko-Adjei, 2019; Lahiry $v d$., 2019). Sosyal medyanın akademik performansa ve kişilerarası ilişkilere etkisi de ispatlanmıştır (Lahiry vd., 2019).

Belirtilen çerçevede kurgulanan araştırma kapsamı ve yöntemi müteakip bölümde anlatılmaktadır.

\section{Yöntem}

Araştırma, Süleyman Demirel Üniversitesi Mimarlık Fakültesi Şehir ve Bölge Planlama Bölümü Planlama Projesi I dersine kayıtlı birinci sınıf öğrencilerinin kimliklerini tespit etmeye dair anket (Ek 1), anketin değerlendirilmesi ve bazı bulguların birinci ve ikinci eğitim dönemi sonu akademik performanslarıyla karşılaştırılması biçiminde tasarlanmış; literatür taramasıyla desteklenmiştir. Araştırma verileri; anket verileri ile, yıl boyu yapılan sınıf gözlemleri ve öğrencilerin akademik performanslarından oluşmaktadır. Durumun resmedilmesinde esas olan betimsel istatistiki yöntem (Karasar, 1994) ve gözlem yöntemi bu örneklem bazında uygulanmıştır.

Öğrencinin sorulara verdiği cevaplarla akademik performansının ilişkisi, tasarım odaklı düşünce ve yaratıcı düşünce oluşumundaki ölçüt olarak belirlenmiştir. Bulguların genellenebilirlik seviyesini belirlemek için anket yöntemi tercih edilmiştir. Bazı bulguların yerindeliği sorgulanarak savın geçerliliğinin tespiti amaçlanmıştır. Araştırma sonucunda, yaratıcı düşüncenin oluşmasına etki eden öğrencinin kimliğinden kaynaklı faktörler kategorize edilerek değerlendirilmiştir.

Anket, Gazi Üniversitesi Șehir ve Bölge Planlama Bölümü temel tasarım dersi akademisyenleri tarafından oluşturulan ve 2015 yılından bu yana uygulanan, öğrencinin formasyonunu ve ilgi alanlarını belirleyen ve deneyimlerini ölçen anketten geliştirilerek inşa edilmiştir. Söz konusu anket, Tekel vd. (2016) tarafından bu bölüm 
özelinde değerlendirilmiştir: Otuz üç öğrenci üzerinde yapılan çalışmada, anket ve test sonuçları ile ögrencilerin görsel algılarındaki gelişimi izlemek üzere, iki boyutlu temel tasarım çalışmalarında sergiledikleri başarı düzeyleri arasındaki ilişki karșılaştırmalı olarak sorgulanmıştır.

Araştırmaya temel olan söz konusu anket üzerinde bir ön çalışma yapılmıştır. Elli sekiz sorudan oluşan anket, SDÜ Şehir Planlama Bölümü'nün temel tasarım eğitimindeki öğrenci kültürel birikimi ve formasyonunun analizi ve çözümlemesi için tasarım odaklı düşünce ve yaratıcı düşünce gelişimi ile ilgili olan otuz yedi soruya indirgenmiştir. Ankette; bilgi amaçlı doğrudan seçmeli, doldurmalı ve bilgiyi yakalayabilmek için açık uçlu anlatımlı sorular kullanılmıştır. Pretest uygulanmamıștır.

Anket iki ardışık yılın güz dönemlerinde uygulanmıştır. Araştırma evreni, iki homojen kümedir: PLN 101 Planlama Projesi I dersi 2018-2019 Güz dönemi öğrencileri Grup I ve 2019-2020 Güz Dönemi öğrencileri Grup II. Grup I'de (ders mevcudu yetmiş altı kişi) elli iki öğrenci ve Grup II'de (ders mevcudu seksen kişi) altmış dokuz öğrenci olmak üzere, anket, toplam yüz yirmi bir $(52+69)$ öğrenciye uygulanmıştır. Anketin kontrol değişkeni, Grup II ve her öğrencinin ikinci dönemdeki akademik performansıdır. Tam sayım örneklem seçimi yapılmıştır. Ankete cevap verenler en az 18 yaşındadır.

Araştırma evreninde istatistikî sorgulama yapılmış, yüzde (\%) dağılımları veya sayıları incelenmiş ve varsa, gruplar arasındaki veri tutarlılığ 1 verilmiştir. Elde edilen bulgular; ilgili başlıklar çerçevesinde, tablolar veya diyagramlar halinde aktarılmıştır.

Öğrencinin ebeveynlerinin eğitim seviyesinin öğrencilerin akademik performansıyla ilişkisi irdelenmiștir.

Dönem sırasında ve sonunda dersi bırakan öğrenciler evren kapsamında, yatay veya dikey kayıtla veya ekle-çıkar haftası sonrasında gelen öğrenciler ise, evren haricindedir. Geç kayıt veya yatay geçiş sonrası sınıf mevcudu değiştiğinden, anket uygulanan öğrenci sayısı derse kayıtlı öğrenci sayısından farklıdır. Grup I ve II'deki kullanılabi- lir cevap oranı $\% 96$ 'dır. Anket cevaplarının doluluk oranı ise, $\% 97$ 'dir.

\section{4. Örneklem Bulgulart}

Araştırma bulgularına dair faktör kategorileri aşağıda yer almaktadır:

- Bölüm Tercihi ve Gerekçeleri,

- Öğrenci Kültürel Birikimi,

- Öğrenci Formasyonu ile Ebeveyn Formasyonu ve Mesleki Profili,

- Analitik ve Eleştirel Düşünce Gelişimi.

\subsection{Bölüm Tercihi ve Gerekçeleri}

Planlama Projesi I dersine kayitlı olarak, ankete cevap veren, Grup I ve II öğrencilerinin yaklaşık \%84'ü ilk kez üniversite sınavına girmiştir. Grup I'de 8 kişi, Grup II'de sadece 1 kişi sınavı kazanarak hazırlık sınıfından derse gelmiştir. 1 öğrenci yatay geçiş hakkını kullanmıştır. Grup II'de dikey geçişle bölüme kayıt olanların oranı birinci gruba benzerdir. Öğrencilerin $\% 8,7$ 'si, dersi, ikinci kez tekrar etmektedir. Sınav sonrası hazırlık sınıfını okuyan, yatay geçiş yapan ve durumunu beyan etmeyen kişiler vardır.

Anketten ve ders tanışma toplantılarından, öğrencilerin çoğunluğunun farklı meslekleri (ebelik, hemşirelik, havacllık mühendisliği, diyetetik $v b$.) hedeflediği ve sadece yüzde kırka yakın bir kısmının bu bölümü bilinçli olarak tercih ettiği belirlenmiștir (Grup I ilk sira tercih $\% 38,5$ ve Grup II ilk sira tercih $\% 42$ ). Öğrencilerin bir kısmı Mimarlık Bölümü'nü hedeflemis (Grup I Mimarlk (\%34,6) ve Grup II Mimarlık (\%27,5)); puanı yetmediği için okuduğu bölümü tercih etmiștir (Sekil 1a) Veriler, Denel (1979)'in mimarlığın ilk tercih olduğu ve öğrencilerin nadir olarak bilinçli tercihle geldiği yönündeki savına uyumludur.

Öğrencilerin bölümü tercih etme gerekçesi sorgulandığında; Grup I denekleri, on dokuz farklı gerekçe bildirmiştir: Yaratıcılığa dair bölüm olması, tasarımı sevmesi, hayal gücünü geliştirmesi ve farklı açılardan düșünmesini sağlaması, şehirlerin kötü gidișatını ve toplumsal bozulmayı engelleyebilecek imkânı vermesi gibi gerekçeler eșit oranda tercih edilen; kent, planlama ve tasarım boyutu olan gerekçelerdir. Bölümü 
zevkli bulan veya hoşlandığı için seçenlerin yarısından fazlasının notu CC'nin altındadır. Bölümü, Mimarlık Fakültesi bölümü ve tasarım ağırlıklı olması nedeniyle tercih eden on öğrenci, $\mathrm{CC}$ altı performans göstermiş̧tir. $\mathrm{Bu}$ öğrencilerden 4’ü dersten kalmıştır. Düşük performans gösteren diğer 3 öğrenci ise, Bahar dönemi temel tasarım dersinden DD alarak dersi geçebilmiştir. Bu durum, Günay (2007) ve Sarıoğlu Erdoğdu (2016)'nun bahsini ettiği somut ve soyut geçişindeki zorlanmanın göstergesidir.

Grup II deneklerince siralanan yirmi alt1 gerekçe arasında yaratıcı düşüncenin varlığ , oluşumu veya geliştirilmesine dair bir gerekçe belirtilmemiştir (Şekil lb). Sadece bir öğrenci; bölümü tercih etme nedeni olarak, hayal gücüne güvendiğini ve bölümün bu gücü geliştireceğini düşündüğünü belirtmiştir. Tasarımı sevme, sevebileceğini düşünme, çizimine güvenme ve çizimini geliştireceğini düşünme, planlamayı ve şehirleri sevme gibi eşit oranda belirtilen gerekçelerin tasarım ve planlama boyutu vardır. Bölümü, Mimarlık Fakültesi’nin bir bölümü olması nedeniyle tercih eden sekiz denekten altısı dersten DC veya altı not almıştır. Bir kişi bölümü bırakmıştır. Bahar döneminde temel tasarım dersine devam eden bu altı öğrenciden ikisi dersten kalnotu DC ve üzeri değildir.

Temel tasarım dersinin geçme notu otuzbeştir. Ancak sistemde yapılan iki farklı hesap (sinff ortalamasl, vize final ortalamasl) sonucunda öğrenci dersten son not otuzsekiz dahi alsa kalabilmektedir. Bu durum, her dönemde sınıfin dersteki akademik mış, biri bütünlemede geçmiştir. Hiçbirinin

başarısına ve öğrencinin vize başarısına göre değişebilmektedir. Öğrencilerin bir kısmı, tasarım eğitiminin önemini süreç dâhilinde kavrayarak çabalamakla birlikte, algı seviyelerindeki düşüklük veya çeşitli dışsallıklar nedeniyle başarısız olmaktadır.

Yerleştirme sınav puan aralığı ve türü homojendir. Dolayısıyla, öğrencilerin tamamının algı, anlama ve okuma beceri seviyeleri benzerdir. Teslimlerden ve teorik anlatım ve kritikler sırasındaki soru ve cevaplardan; öğrencilerin dikkat eksikliği, dilbilgisi yokluğu yanı sıra, genel kültür düzeyleri ile matematik ve geometri bilgilerinin de yetersiz olduğu belirlenmiştir. Öğrencilerin, kısa süreli bellek ile uzun süreli bellek (Kaptan vd., 2019; Seylan, 2019) irtibatı kesik olduğundan, derste anlatılan konuları ve istemleri müteakip derste hatırlayamadıkları, alıştırmaya yansıtamadıkları, araştırma ve bilgi içermeyen tasarım ürettikleri ve bizzat yaptıkları alıştırmanın içeriklerini daha sonra sözel ve yazılı sorularda cevaplayamadıkları gözlemlenmiştir.

Öğrenciler, uygulama föylerini okumamakta, okusa dahi istemi ifade edememektedir. Enformasyon yoluyla hatalı ve/veya eksik bilgi alarak (desenformasyona göre) istem dış1 ürünler üretmektedir. Bu durum, ürünlerin föyde belirtilen istemlerle alakasız olmasından anlaşılabilmektedir. Öğrenci, sadece yazılanı okuyabildiğinden, stüdyo uygulamalarında veya ödev ürünlerin kritiğinde anlatılanları anlamamakta, anlamadıklarını ifade etmemekte/edememekte ve anlamak isteme yönünde bir çaba da harcamamaktadır. Araştırma ve analizleri bilinçli olarak yapmadıkları ve/veya önceki uygulamaların devamı niteliğindeki uygulamalarda;

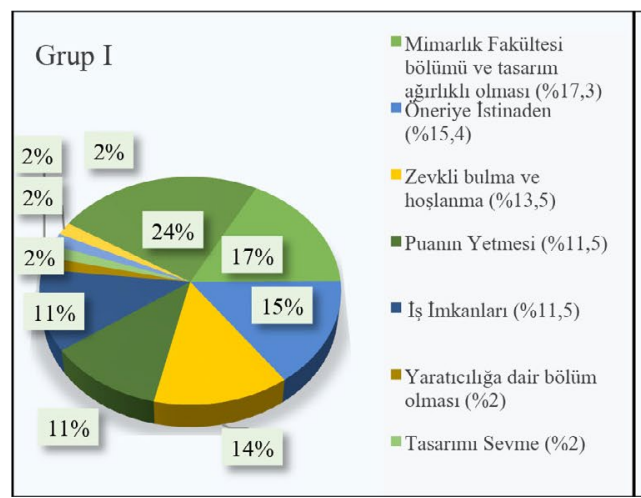

Şekil: I Bölüm Tercih Gerekçesi (\%). a. (sol) Grup I, b. (să̆) Grup II. 
Şekil: 2

a. (Sol) Grup I Dönem Sonu Notları, b. (Să̆)

II. Dönem Sonu Not Değişimi. istemlerin gereği konular ile teknik çizim aletlerinin, matematiğin, geometrinin kullanımını bağdaştıramadıkları da belirlenmiştir. Ödevin hazırlanmasını teslim öncesi güne veya geceye bırakma, derse ilgisizlik veya katılmama veya ödevi teslim etmeme yaygın davranış biçimleridir.

Araştırma evreninin akademik performansı benzerdir. Grup I anketini cevaplayan elli iki denekten on iki adedi $(\% 23,1)$ başarısız olarak dersten kalmıştır (Şekil 2a). Grup I'den 39 öğrenci Bahar dönemi dersine devam etmiştir. Devam eden öğrencilerden bir adedi dersten kalmıştır. Söz konusu öğrencilerin yarısının notu düşmüş, üçte birinin notu değişmemiş ve sadece beşte birinin notu yükselmiştir (Şekil 2b) Grup II anketini cevaplayan altmış dokuz öğrenciden on üç adedi, derste başarısız olarak kalmıştır (Şekil 3a). Gruptan elli dört öğrenci, Bahar dönemi dersine devam etmiştir. Öğrencilerin çoğunluğunun notu yükselmiştir (Şekil 3b). Bu durumun, Covid-19 Pandemi dönemi çevrimiçi eğitim metodo- lojisine geçişe bağlı olduğu değerlendirilmektedir.

Grup I ve II'de BB ve üstü alan öğrencilerin ortak noktaları; görsel sanatlara ilgili olduklarını belirtmiş olmaları, dersteki girişkenlikleri ile tasar üretim yönündeki istek ve çabalarıdır.

Grup I ve Grup II öğrencilerinden toplam sekiz adedinin iyi not (BB ve üzeri not) alması, analiz evrenindeki genel başarı düzeyindeki düşüklüğün farklı bir göstergesidir. Biri 'süper lise' diğerleri Anadolu Lisesi mezunu olan bu grubun, ders disiplinleri ve katılımları ile kişiliklerinin daha gelişmiş olduğu gözlemlenmiştir. Çoğunun annesi ev hanımı ve ilkokul veya ortaokul mezunu, bir öğrencinin annesi ise, lise mezunudur. Bazı öğrenciler, annelerinin eğitim durumunu belirtmemişlerdir. Babaların mezuniyeti ise, ilkokul, ortaokul ve üniversite mezunu şeklinde değişkenlik göstermektedir. Özellikle Grup II'de BB ve üstü not alan öğrencilerin babalarının

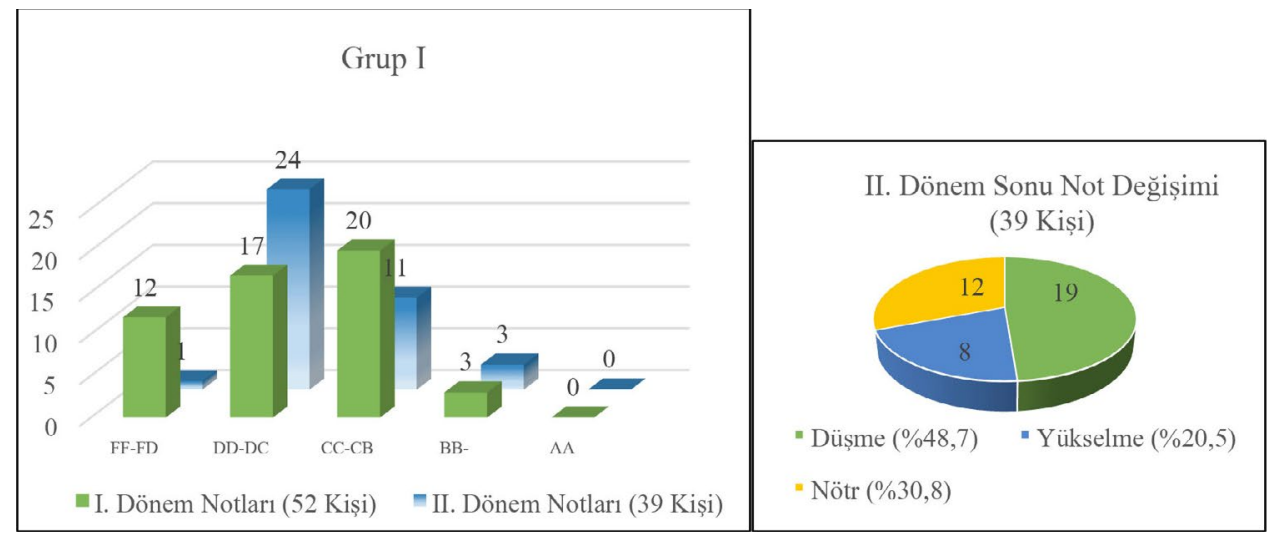

Şekil: 3

a. (Sol) Grup II Dönem Sonu Notları, b. (Să̌)

II. Dönem Sonu Not Değişimi.

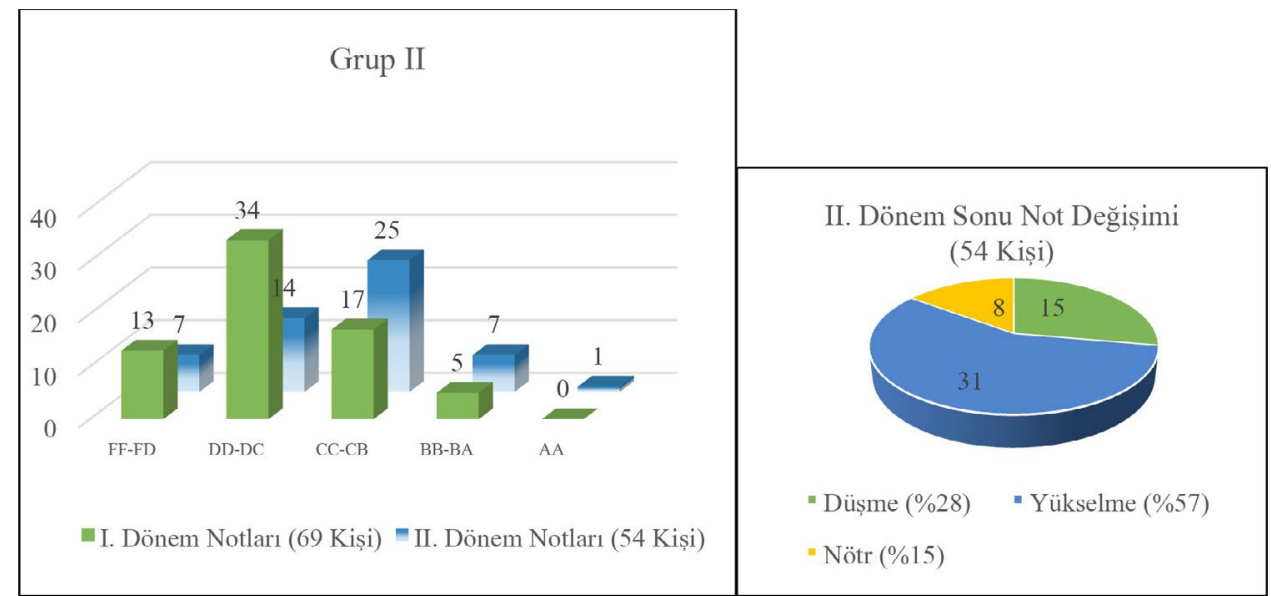

Sayı 34, Kasım 2021 
eğitim durumundaki yükseklik, Nelson (2009)'un tespitine benzerdir.

Grup I'deki yüksek not alan üç kişi 237244 puan aralığındadır. Bölüm, bu öğrencilerin çoğunun öncelikli tercihi değildir. Grup II'de yüksek not alan 5 kişinin genel tercihi Şehir Planlama'dır ve incelemeye konu üniversite bölümü, tercih sıralamasında Grup I'den farklı olarak; 1'den 4'e kadar olan tercih sıralaması içindedir. Söz konusu öğrencilerin başarı puanı ise, 245-265 arasındadır. Başarılı öğrencilerin bölümü isteyerek seçtikleri ifade edilebilir.

Düşük notların ikinci temel nedeni; üniversitenin ülke taban puanları ve başarı sıralamasındaki yeri ve bu yerin öğrencinin başarısıyla olan ilişsisidir. Bir Şehir ve Bölge Planlama öğrencisi, üniversite sınavında, Temel Yeterlilik Testi (TYT) ile bölüme yerleșmektedir. Bölüme, 2018 y1linda 236,63205-295,60543 ve 2019 yılında 243,06899-302,47794 sayısal puan aralığında öğrenci alınmıștır (SDÜ Mimarlık Fakültesi, 2020; YÖK Atlas, 2018, 2019). 2018 yılında Yüksek Öğretim Kurumları Sınavı (YKS) başarı sırasına göre, en üst puan alan öğrenci \%21,33'lük dilimde, en düşük puan alan öğrenci ise \%38,55'lik dilimde bölüme gelirken; 2019 y1lında, dilim aralığı, en üst $\% 21,72$ ve en düşük puan \%47,94 dilimde kaydedilmiştir. Başarı puanlarındaki düşüs belirgindir.

Şehir Planlama Bölümü lisans eğitimi, 2018 yılında, yirmi yedi üniversite arasında on dokuzuncu sırada; 2019 yılında otuz bir üniversite programı arasında yirminci sirada yer almaktadır (SBP TPBS, 2018; 2019). Şehir Planlama bölümleri arasında birinci sırada yer alan Orta Doğu Teknik Üniversitesi'nin 2018 yılında YKS başarı sırasına göre, en yüksek puan alan öğrencisi $\% 2,83$ ve en düşük puan alan öğrencisi $\% 6,10$ 'lık dilimdedir. 2019 yılında en yüksek puanla bölüme giren öğrenci \%3,29 ve en düşük puanı alan öğrenci \% 7,46'lık dilimdedir. Lawson ve Dorst (2009)'un betimlediği formüle etme, Dorst (2011)'in belirttiği tasarımın tümevarım ve problem çözme üzerine yapılandığı savlarından hareketle, YKS'nda gösterilen başarının akademik başarı seviyesini belirlediği iddia edilebilir.

\subsection{Kültürel Bilgi Birikimi}

Disiplin alanı eğitiminin görsel sanatlarla bağlantısı nedeniyle ve öğrencinin kişiliğine etki eden kültürel bilgi birikim düzeyinin anlaşılabilmesi amacıyla, öğrencinin görsel sanatlara, arkeolojiye ve sanat tarihine ilgisi yanı sıra; farklı kentlere seyahati, sosyo-kültürel etkinliklere katılım düzeyi, kitap okuma alışkanlığı, izlediği filmler ve TV programları ile bilgisayar oyun deneyimi sorgulanmıştır.

Grup I ve Grup II'nin yaklaşık yüzde altmışı arkeolojiye ilgi duymaktadır. Farklı bir ders kapsamında yapılan antik kent saha çalışması sırasında gelen sorular ve tepkilerden, daha önce herhangi bir arkeolojik sit alanı görmemiş olan öğrencilerin, ders etkinliği sayesinde arkeolojiye, kent ve kentleşme tarihine merak sardığı belirlenmiştir. Sanat tarihine ise, her iki grubun önemli bir kısmı (Grup I\%67,3, Grup II \%46,4) ilgisizdir.

Görsel sanatlar, her iki grubun deneklerinin yaklaşık dörtte üçünün ilgi alanına girmektedir. Grup I'den sadece üç öğrenci sergi ve sanat galerilerine sıklıkla gitmektedir. Grup II'de ise, bu oran tam iki katıdır. Tekel vd. (2016)'ne göre, öğrencinin görsel sanatlarla ilgili deneyimi olmasa da, etkinliklere gitmesi ve izlemesi görsel algı düzeyini geliştirmektedir. Evrenin çoğunluğunun algısını ve dimağını geliştirecek sergi ve galeri kültürünü oluşturmak için eğitim sürecinde herhangi bir çaba harcamadığg belirlenmiştir.

Öğrencinin el sanatları veya resim gibi görsel sanat kurslarına katılımı sorgulandığında, Grup I'in deneklerinin tamamına yakınının herhangi bir el sanatları kursuna gitmediği belirlenmiştir. Grup II'de bu oran daha düşüktür. Grupların boş zamanlarında el sanatlarıyla uğraşma oranı da benzerdir (Grup I \%69, 2 ve Grup II \%65). Grup I ve II deneklerinin çoğunluğu resim yapmaktan hoşlanmaktadır. Boş zamanlarında resim yapanların oranı, her iki grupta yaklaşık yüzde kırktır.

Görsel sanatların bir dalı olan heykel konusunda ise, her iki grupta herhangi bir birikim ve üretim bulunmamaktadır. Grup I'den sadece bir kişi boş zamanlarında 
heykelle uğraşmaktadır. Grup II'de bu sayı ikidir. Benzer bir tespit, fotoğrafçılıkla ilgilidir. Deneklere fotoğraf çekme konusu sorulduğunda, Grup I ve II deneklerinin yaklaşı yüzde doksanı fotoğraf çekimini sevdiğini belirtmekte; profesyonel olarak fotoğraf çekim oranı ise, iki grup arasında farkl111k göstermektedir (Grup I\%1,9, Grup II $\% 10,1)$.

Kültürel bilgi birikimini tespit etmeye dair bir diğer faktör, öğrencinin etkileşimde olduğu kentlerle alakalıdır. Deneklerden yurtdışında gezdiği kentler ile ülkesinde gördüğü (üniversitesinin ve kalıcı adresinin bulunduğu kentler dışındaki) büyük kentleri listelemesi istenilmiştir. Deneklerin yurtdışındaki bir kenti görme oranı ve yurtiçi hareketlik düzeyi düşüktür. BB ve üstü alan öğrencilerin hareketliliği, nispeten yüksektir. Grup I denekleri, toplamda 155 defa farklı bir kente gittiklerini beyan etmiştir. En fazla seyahat edilen kentler sirasıyla; Ankara, İstanbul, İzmir, Antalya, Bursa, Konya, Trabzon, Çanakkale, Erzurum'dur (Şekil 4a). Herhangi bir büyük kenti görmemiş beş öğrenci vardır. Grup II denekleri toplamda 198 kente gitmiştir. Öğrenciler, sırasıyla; İstanbul, Ankara, İzmir, Antalya, Çanakkale, Bursa, Konya ve Samsun'a gitmiştir. Şekil 4b. Seyahat etmekten ve yeni yerler görmekten hoşlanma oranı ise, yüksektir (Grup I\%98,1 ve Grup II \%95,7).

Öğrencilerin sosyo-kültürel etkinlikleri, her iki grupta, sinema, konser ve festival aktiviteleri şeklindedir. Grup I öğrencilerinin yaklaşık yüzde yirmisinin, Grup II öğrencilerinin ise, yüzde yirmi üçünün herhangi bir kültürel etkinliğe katılımı

Sekil: 4

Öğrencilerin Seyahat Ettiği Büyük Kentler. a. (sol) Grup l, b. (să̆) Grup II.

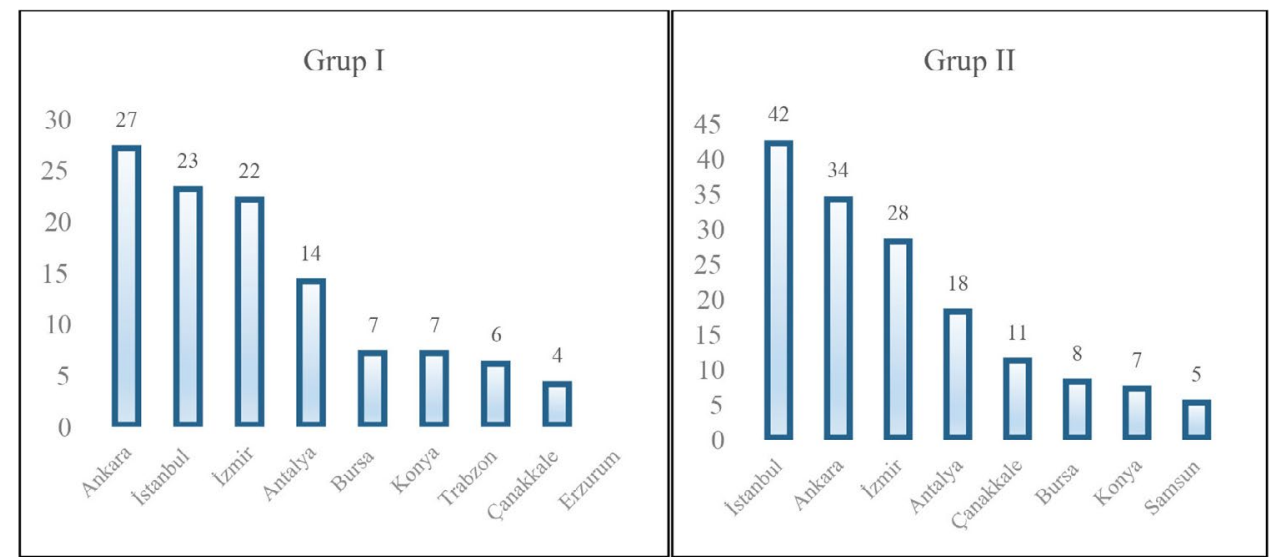

Sayı 34, Kasim 2021 
Eğitim sürecinde bilgisayar oyunu oynayan öğrencilerin başarısız olduğu gözlemlenmiştir (Şekil 5a). Grup II'de oyun oynamanın etkisi daha belirgindir (Şekil 5b). Oyun oynadığını belirten deneklerin çoğunun notları düşüktür. Oyun oynadığını belirten bir öğrenci (Grup I Denek 51) Güz döneminde dersten geçse de, Bahar döneminde kalmıştır. Grup I anketine katılmayan ve oyun oynaması nedeniyle dersten kaldığı için Grup II ile birlikte ankete cevap veren öğrenci (Grup II Denek 35) ikinci tekrarında dersi geçebilmiştir. Dönem boyunca sanal oyun oynadığı gözlenen bazı öğrencilerin ankette oyun oynamadığını beyan ettikleri belirlenmiştir.

Oyunların sadece bireysel oynanmadığı, bazı sanal liglerin kurulu olduğu ve bu liglerde oynayabilmek için öğrencilerin takım arkadaşlarının yer aldığı üniversitelere kaymaya çalıştıkları gözlemlenmiştir. Ödevleri teslim etmeme, uykusuz sınıfa gelme ve dersten kalma oyun bağımlılarının standart davranış biçimleridir.

Oyunların sanal ortamı veya hayal sahnesi, yaratıcı bir ortamdır ve öğrencinin hayal gücünü geliştirmesi beklenmektedir. Bazı tasarım okullarının uygulamalarında
SIMcity BuildIt, Hayal Edilebilir Tasarim Kilavuzu (YEM Yayın) gibi oyunlar, öğrencilerin düşünce ve hayal düzeylerini arttırmak için bilinçli olarak oynatılmaktadır. Eğitmen kontrolü dışında oynanan bilgisayar oyunları akademik başarısızlığın bir diğer nedenidir.

Öğrencinin sosyo-kültürel geçmişinin göstergelerinden biri de, öğrencinin hobileri ve uğraş alanlarıdır. Kitap okumak, müzik dinlemek, resim yapmak, futbol, basketbol veya voleybol oynamak, film izlemek, keşif yapmak/gezmek, bilgisayar oyunu oynamak her iki gruptaki en yaygın eylemlerdir. Grup I öğrencilerinin Grup II öğrencilerine göre eylem çeşitliliği fazladır. Her iki grup deneklerinin genelde film, belgesel, dizi, spor, magazin ve haber izlediği belirlenmiştir. Film türleri; bilimkurgu, macera, komedi, gerilim, dram, polisiye, biyografi ve politik filmlerdir. Haber izleme oranı ise, düşüktür (Şekil 6).

\section{3. Öğrenci Formasyonu ile Ebeveyn Formasyonu ve Meslek Profilleri}

$\mathrm{Bu}$ kısımda öğrencinin mezun olduğu ortaöğretim kurumu ile ebeveynlerin mesleki profili incelenmiştir. Grup I'in deneklerinin \%67,3'ü ve Grup II'nin \%71'i Anadolu Li-
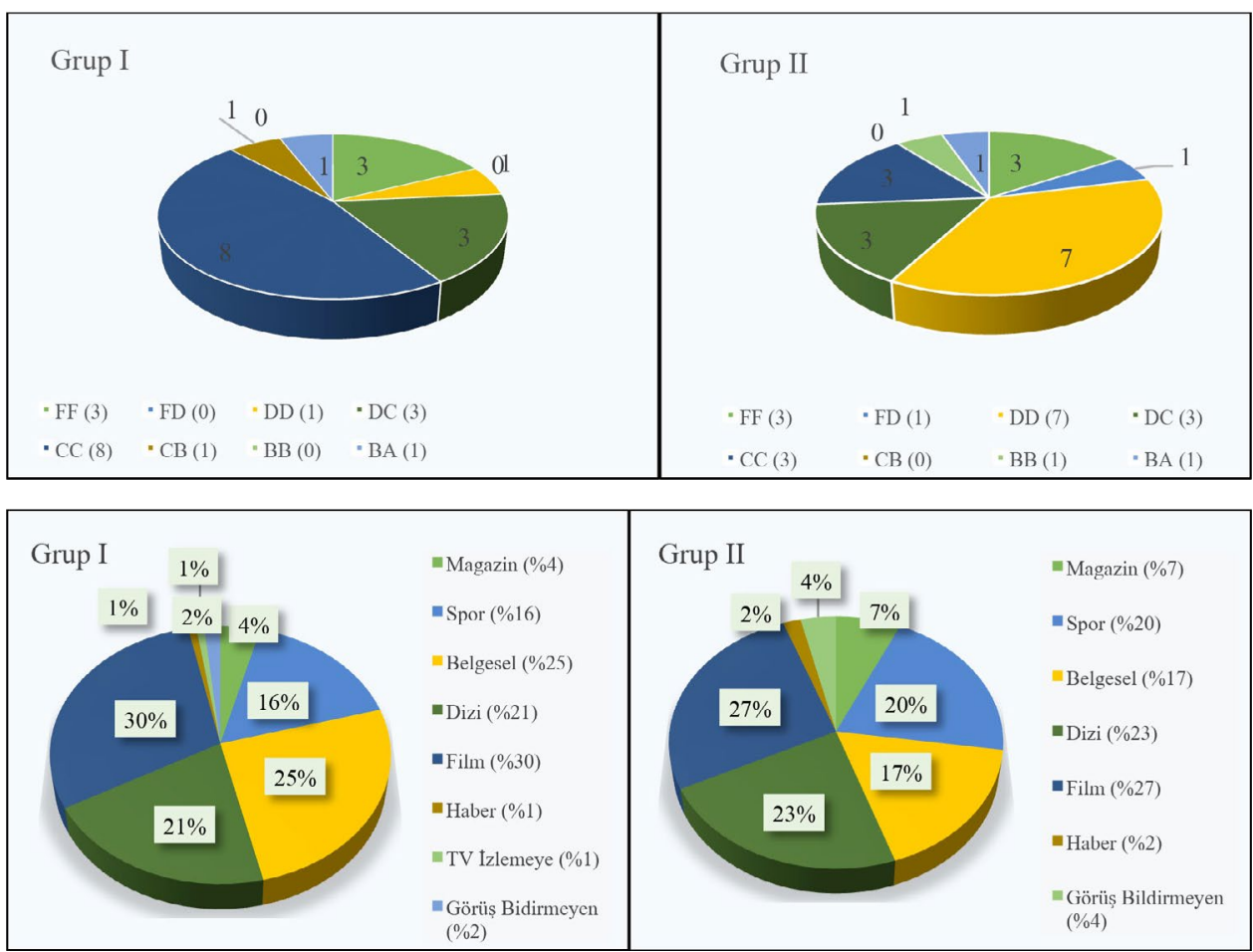

sekil: 6

Ögrrencilerin Izlediği TV Programı Türleri. a. (sol) Grup I, b. (să̆) Grup II.
Şekil: 5

Akademik Performans-Bilgisayar Oyunu ilişkisi. a. (sol) Grup I, b. (să̆) Grup II.

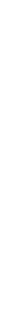


Şekil: 7

Mezun Olunan Ortaögretim Kurumu. a. (sol) Grup I, b. (să̆) Grup II.

Tablo: I

Grup I, Anne Formasyonu ve Meslek Profili.

Tablo: 2

Grup I, Baba Formasyonu ve Meslek Profili.

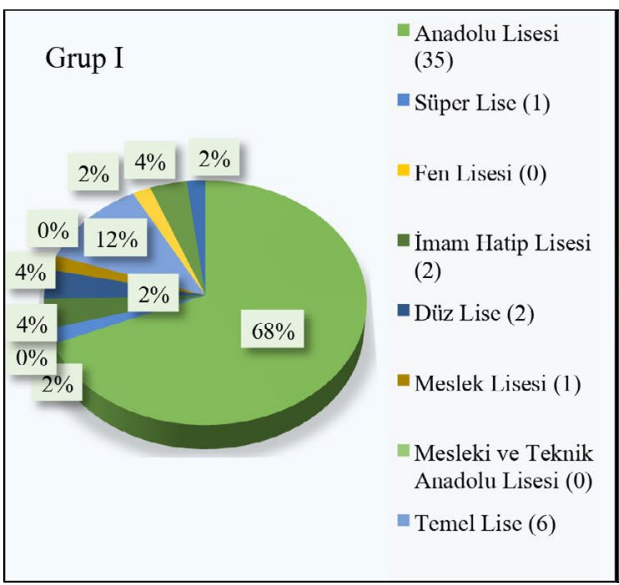

sesi mezunudur. Mezun olunan diğer okul türleri Şekil 7'de yer almaktadır.

Öğrencinin kimliği ve kişiliği, anne ve babanın kimliğiyle şekillendiğinden, anne-baba formasyonu yaratıcı düşünce oluşumu ve gelişimine etki eden bir faktör olarak değerlendirilmektedir. Grup I deneklerinin anne formasyonu ve meslek profili; ağırlıklı olarak, ilkokul, ortaokul veya lise mezunu ev hanımlarından oluşmaktadır. Üniversite mezunu anne sayısı elli iki kişide sadece dört kișidir (Tablo 1). Babanın meslek profili; serbest meslek erbabı, özel

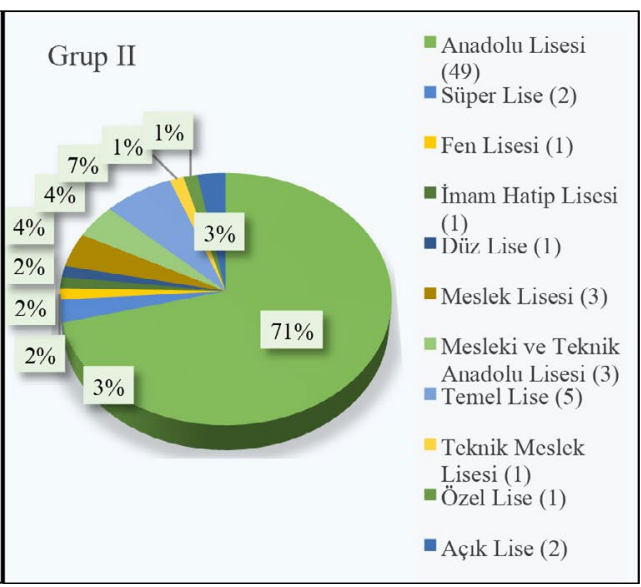

sektör çalışanı, memur veya çiftçiden oluşmaktadır. Babaların sadece \%17,3'ü lisans mezunudur (Tablo 2 ve Sekil 8). Grup II deneklerinin anneleri; genelde, ilkokul, ortaokul veya lise mezunu ev hanımı, işçi veya özel sektör çalışanıdır (Tablo 3). Babanın meslek profilinde; serbest meslek erbabı, özel sektör çalışanı ve emekli yer almaktadır. Babaların \%18,8'i lisans mezunudur (Tablo 4 ve Şekil 9).

Grup I deneklerinden Güz dönemi dersinden kalanların annelerinin çoğunluğu ev hanımı ve ilkokul veya lise mezunu; ba-

\begin{tabular}{|c|c|c|c|c|c|c|c|}
\hline Eğitim/Meslek & İlkokul Terk & İlkokul & Ortaokul & Lise & Ön Lisans & Lisans & Eğitim Durumu (Belirsiz) \\
\hline Ev hanımı & 1 & 20 & 8 & 9 & & & 1 \\
\hline Özel Sektör Çalışanı* & & 4 & & 2 & & 2 & \\
\hline Özel Sektör Ticaret Erbabı & & 1 & & & & & \\
\hline \multicolumn{8}{|l|}{ Öğretmen } \\
\hline Emekli** & & & & 1 & & 2 & \\
\hline Meslek (Belirsiz) & 1 & & & & & & \\
\hline Toplam (52) & 2 & 25 & 8 & 12 & - & 4 & 1 \\
\hline
\end{tabular}

\begin{tabular}{|l|l|c|c|c|c|c|c|}
\hline Eğitim/Meslek & Ilkokul Terk & Ilkokul & Ortaokul & Lise & Ön Lisans & Lisans & Ĕgitim Durumu (Belirsiz) \\
\hline Çiftçi & & 2 & 1 & 1 & & & \\
\hline Özel Sektör Çalışanı & & 3 & 2 & 2 & & 2 & 1 \\
\hline Özel Sektör Ticaret Erbabı & & 7 & 4 & 4 & & 1 & 1 \\
\hline Memur & & 1 & 2 & 3 & & 1 & 1 \\
\hline Öğretmen & & & & & & 2 & 1 \\
\hline Emekli & & 1 & & 5 & 1 & & \\
\hline Asker & & & & & & 2 & \\
\hline İşsiz & & & & & & & \\
\hline Meslek (Belirsiz) & & 2 & & & & & \\
\hline Toplam (52) & & 16 & 9 & 15 & 1 & 9 & \\
\hline
\end{tabular}


baları ise, işçi, emekli veya serbest meslek mensubu ve çoğunlukla lise mezunudur. Grup II de ise, annelerin çoğunluğu ev hanımı ve ilkokul mezunudur. Babaların farklı meslek gruplarında çalıştığı ve genelde ilkokul veya lise mezunu oldukları belirlenmiştir.

\subsection{Analitik ve Eleştirel Düşünce Gelişsimi}

Hayalgücü eksikliği ayrıca, göz-el-zihin arasındaki ilişkiyi kuramama anlamına gelmektedir. Öğrencilerdeki hayal gücünün eksikliği, anaokulundan itibaren hayalgücünün öğrencide gelişmediğinin göstergesidir. Şekil 10'da sınıfin bir arada hayal ederek 3-boyutlu bir tasarımı (Paris Küpleri alşstrması) gerçekleştirme anının görüntüsü yer almaktadır. Bir kısım öğrenci grup çalışmasına karşı ilgisizdir.

Kümelerdeki anaokuluna gitme oranları benzer ve yarıdan fazladır. Öğrencilerin anaokulu eğitimlerinin düşünce gelişimine katkısını belirlemek amacıyla, dersten kalan ve dersten $C B$ ve üstü not alan deneklerin anaokulu geçmişleri irdelenmiştir. Grup

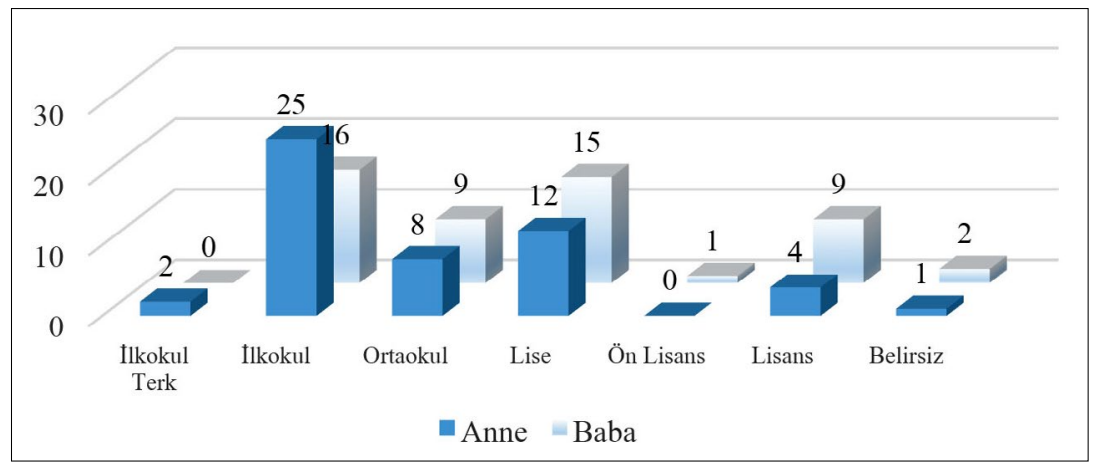

I'de anaokuluna gidenlerin yarısı dönem sonunda CC ve üstü not alırken, Grup Grup I, Anne-Baba Formasyonu. II'nin yaklaşık yüzde yirmisi CC ve üstü not alabilmiştir. Grup I'de CB-AA arası not alan 5 kişiden 3'ü, FF-FD arası not alan onbir kişiden altısı anaokuluna gitmiştir. Grup II'de CB-AA arası not alan 3 ve FF-FD arası not alan 7 öğrencinin anaokulu geçmişi vardır. Anaokulu eğitimi alan başarılı ve başarısız öğrenciler arasında bir fark yoktur. Anaokulu eğitiminin süresi ve niteliği belirsiz ve her iki grupta dengeli bir dağılımı olduğundan, bu aşamada anaokulu eğitimi alan bireylerin yaratıcı düşünce ko-
Tablo: 3

Grup II, Anne Formasyonu ve Meslek Profili.

Tablo: 4

Grup II, Baba Formasyonu ve Meslek Profili.

\begin{tabular}{|c|c|c|c|c|c|c|c|}
\hline Ĕgitim/Meslek & İlkokul Terk & İlkokul & Ortaokul & Lise & Ön Lisans & Lisans & Belirsiz \\
\hline Ev hanımı & 3 & 15 & 11 & 9 & & & 5 \\
\hline Özel Sektör Çalışanı* & & 7 & 2 & 4 & & 1 & \\
\hline Özel Sektör Ticaret Erbabı & & & & 2 & & 1 & \\
\hline Öğretmen & & & & 1 & & 3 & \\
\hline Emekli** & & & & 1 & & & 1 \\
\hline Meslek (Belirsiz) & & & 1 & & 1 & & 1 \\
\hline Toplam (69) & 3 & 22 & 14 & 17 & 1 & 5 & 7 \\
\hline
\end{tabular}

\begin{tabular}{|c|c|c|c|c|c|c|c|}
\hline Ĕ̆itim/Meslek & İlkokul Terk & İlkokul & Ortaokul & Lise & Ön Lisans & Lisans & Belirsiz \\
\hline Çiftçi/Besici & & 3 & & 1 & & & \\
\hline Özel Sektör Çalışanı * & & 7 & 3 & 6 & 1 & 1 & \\
\hline Özel Sektör Ticaret Erbab1 ** & & 4 & 4 & 8 & & 6 & 1 \\
\hline Memur $* * *$ & & & & & & 3 & \\
\hline Öğretmen & & & & & & 2 & \\
\hline Emekli $* * * *$ & & 1 & 1 & 2 & 1 & 1 & 5 \\
\hline Kaptan & & & 1 & & & & \\
\hline İşsiz & & 1 & & & & & \\
\hline Meslek (Belirsiz) & & 2 & 1 & & & & 3 \\
\hline Toplam (69) & & 18 & 10 & 17 & 2 & 13 & 9 \\
\hline
\end{tabular}



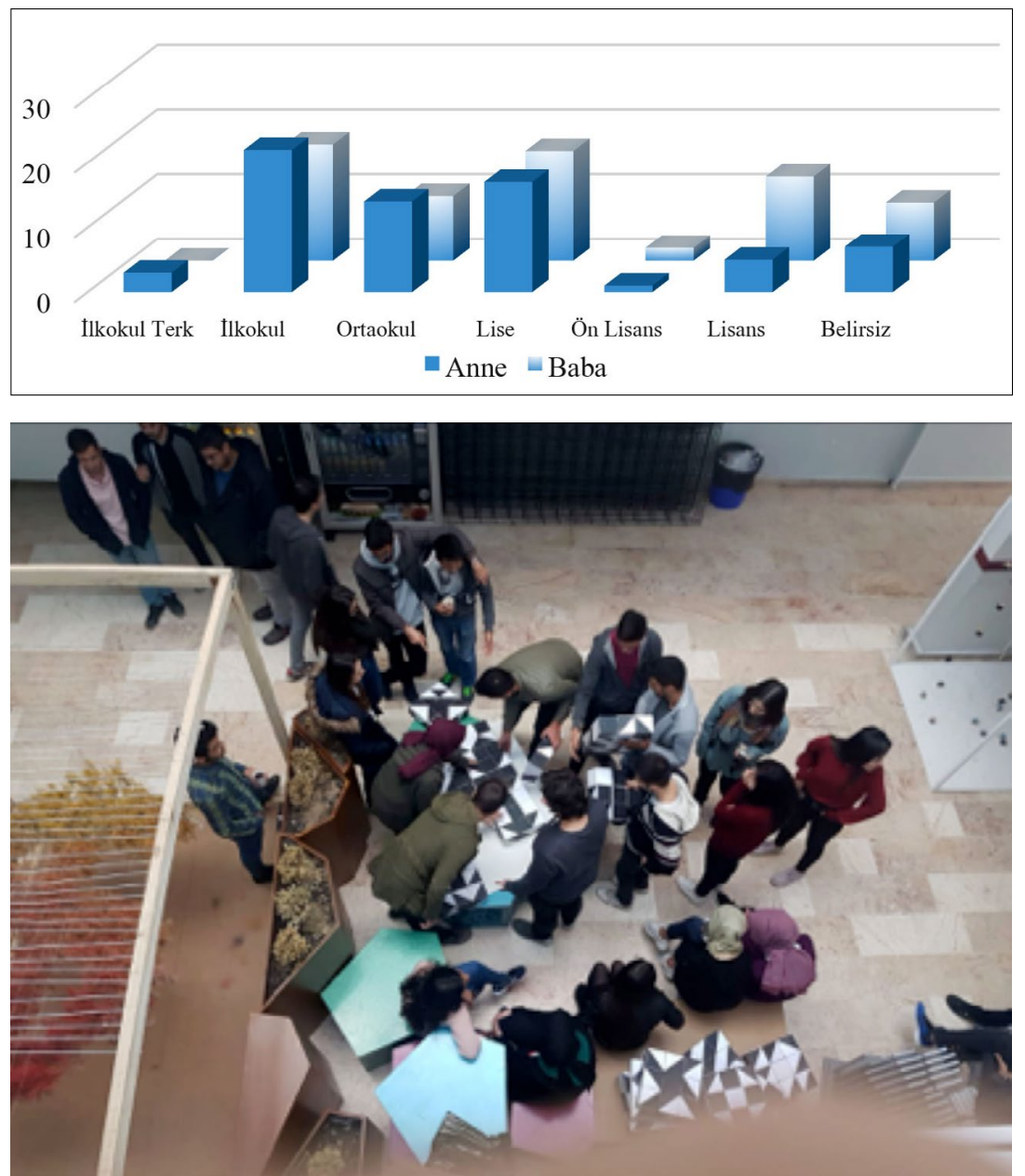

Şekil: 9

Grup II, Anne-Baba Formasyonu.

Şekil: 10

Planlama Projesi I Dersi Grup II Çalışması (Yazarın Çekimi, 2019).

Şekil: II

Dersin Mesleklerine Ilişkin Katması Beklenen Bilgi ve Beceriler. a. (Sol) Grup I, b. (să̆)

Grup II. yeteneği, hayal gücü ve yaratıcı düşüncenin gelişimi, imar planı yapımını öğrenme ve sunum becerisi kazanma, iyi bir planc1 olma, tasarım becerisi edinme, şehir kültürünü öğrenme ve çevreyi algılama beklenti olarak ifade edilmiştir. Analitik düşünme, çok boyutlu düşünme, grup çalışması, matematiksel zekâ, harita bilgisi, bölge planlamaya yeni bakış açısı getirme belirtilen diğer beceri türleridir (Sekil 1la).

Grup II deneklerinin beklentileri; sirasiyla, çizim yeteneği ve yaratıcı düşüncenin gelişimi, hayal gücünün gelişimi, beceri gelişimi, plan yapımı ve şehrin tasarımını düzeltme şeklindedir. Diğer cevaplar; 3-boyutlu maket yapımı, park yapma, estetik düşünme, kentsel sorunları çözme ve alg1 gelişimidir. "İyi bir plancı olma", "kısa sürede plan işi nasıl çıkartılır", "tarihi bilgi edinimi" gibi alakasız cevaplar da mevcuttur (Sekil 11b).

Matematiksel zekâ, tasarımın bir girdisidir. Grup I ve Grup II'nin yaklaşık dörtte üçü matematiksel veya istatistiksel hesaplara ilgi duymaktadır. Her iki grubun karışık problemleri sıkılmadan çözebilme oranı yarıdan fazla ve benzerdir. Sayısal bulmacaları çözmekten hoşlanma oranı, Grup I için \%82,7'dir. Grup II için bu oran $\% 78,3$ 'dir. Belirtilen oranların aksine, öğrencilerde, tasarım problemini, teknik çizim aletleri yanı sıra, matematik ve geometri kullanarak çözme endişesi yoktur. Matematiği kullanan az sayıda öğrenci, s1nıf genelinden ayrışmaktadır. Bu öğrencilerin eğitim sürecinde gözlemlenen çabaları çalışma disiplinleriyle uyumludur.

Sistematik yaklaşımın varlığı, deneğin problemlerin çözümü konusunda formüller

sŭğe doğru sıralanmıştır. Grup I'de çizim

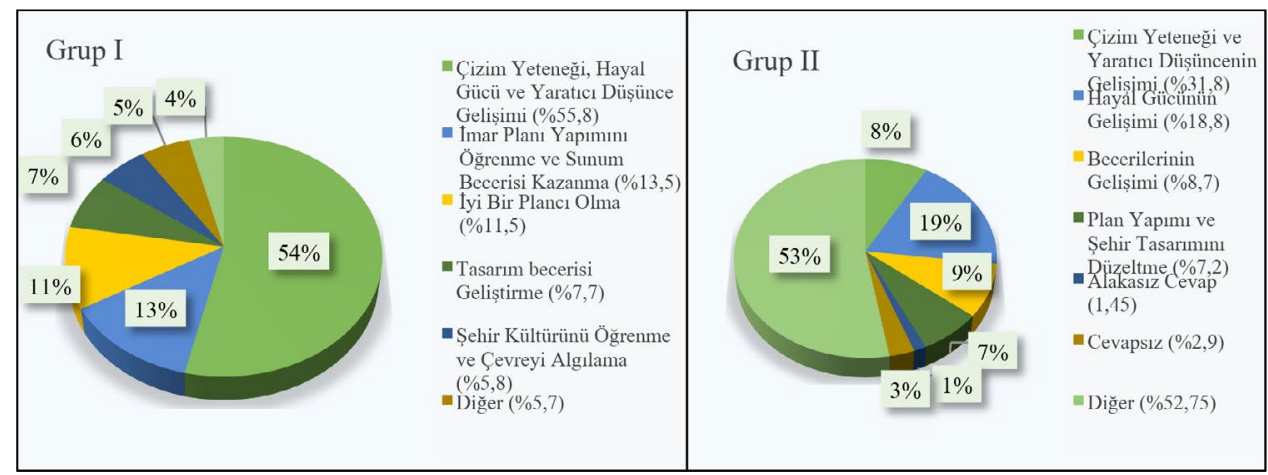




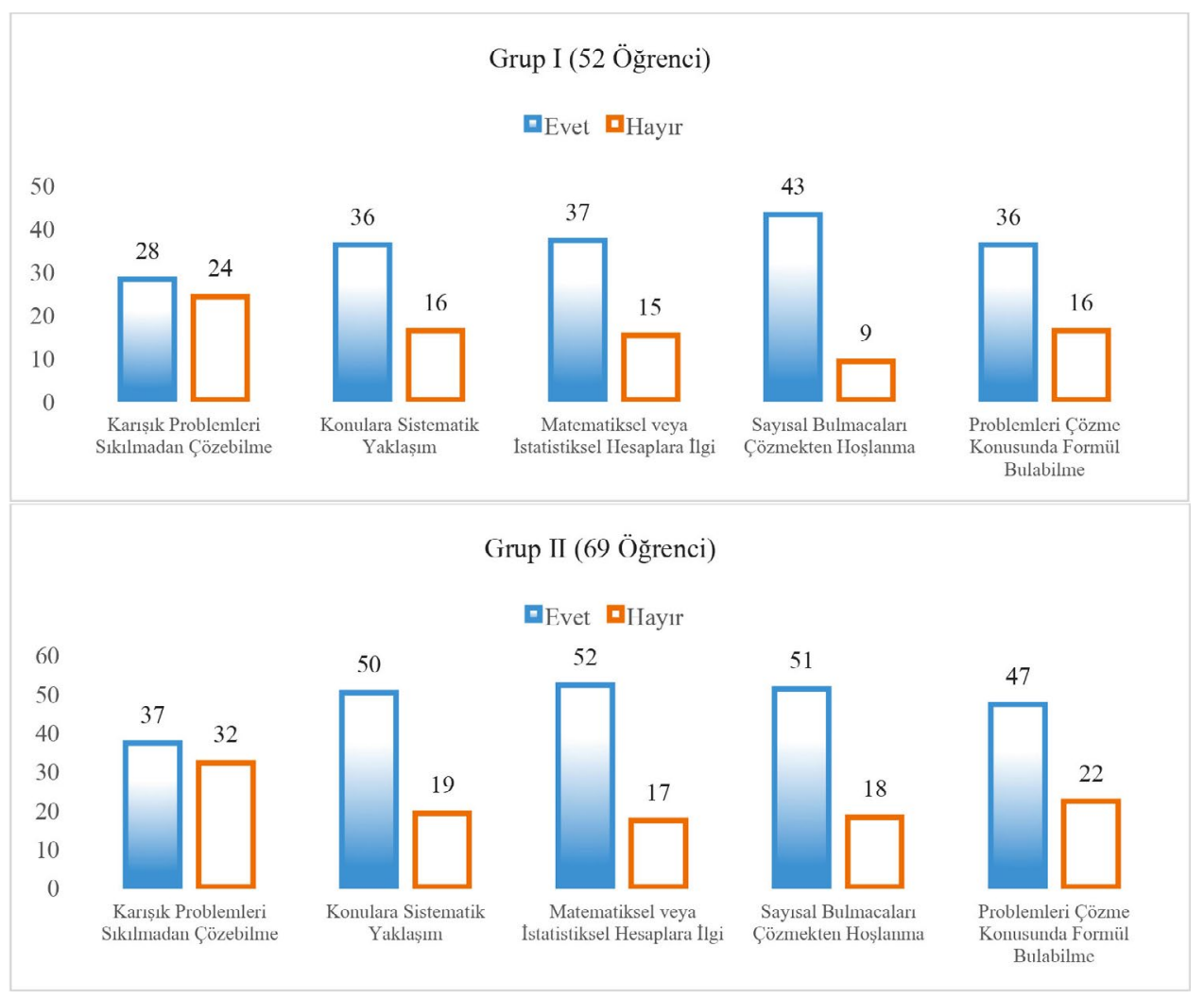

geliştirebilme yetisi ve teknolojik yeniliklere ilgisi bağlamında sorgulanmıştır: Grup I'de öğrencilerin konulara sistematik yaklaşıma sahip olma ve problem çözümü konusunda formüller bulma becerisi oranları aynı ve yaklaşık \%70'tir. Grup II'deki oranlarla benzerdir. Grup I ve II'nin üçte biri, sorun çözümü konusunda bir becerisi olmadığının farkındadır.

Analitik ve sistematik düşünceyi geliştirerek dersi başarıyla tamamlayan $(C C$ ve üstü not alan) her iki grupta aynı sayıda kişi vardır (Yirmi ikişser kişi). Grup I'de ankette konulara sistematik yaklaşım yapmadığını belirten 16 kişiden 7'sinin, Grup II'de ise, 19 kişiden 5'inin CC ve üstü not alması, süreç dâhilinde yaratıcı düşünün gereği sistematik düşüncenin geliştiğinin göstergesidir.

Gruplardaki başarısızlık oranları hemen hemen aynıdır (Sekil 12b). Dersten kalan öğrencilerin çoğunluğu, görsel sanatların ilgi alanına girmesi, karışık problemleri sıkılmadan çözebilme, sayısal bulmacaları çözmekten hoşlanma, problemleri çözme konusunda formül bulabilme ve konu- lara sistematik yaklaşmaya dair sorulara dönem başında olumsuz cevap vermiştir. Denek 40 soruların çoğuna "Hayır" cevabı vermiş ve dersten kalmıştır. Ancak tersi de mevcuttur. Grup I Denek no. 51 ve no. 7 ile Grup II Denek no. 19, bahse konu sorularda "Evet"i seçmelerine rağmen, dersten kalmışlardır. Grup I'de deneklerin önemli bir kısmı ilgili sorulardan bir veya birkaçına "Hayır" cevabı vermiștir.

Grup I evrenindeki sorulardan herhangi birine 'hayır' cevabı veren yirmi dört öğrenciden on yedisi CC altı not almış ve dörtte biri (12 kişi) kalmıştır (Şekil 12a). Grup II'de yaratıcı düşüncenin gelişimini belirlemeye dair sorulardan bir veya birkaçına "Hayır" cevabını veren veya soruyu cevaplamayan denekler otuz bir adettir. Bunların yarısı $\mathrm{CC}$ altı not almış, dört kişi kalmıştır. Grup II'de anketi cevaplayan altmış dokuz öğrenciden on üçü dersten başarısız olmuştur. Bahsi geçen hususlar akademik başarısızlığın göstergesidir.

\section{Genel Değerlendirme}

Temel tasarım eğitimi; teknik açıdan doğru tasarlanmış yaşanabilir mekânı ve
Sekil: 12

Analitik ve Sistematik Düşüncenin Gelişimine Dair Sorulara Cevaplar. a. (Üst) Grup I, 6 . (Alt) Grup II. 
dolayısıyla, toplumu tasarlayacak meslek insanlarının yetiştirildiği temel eğitimdi. Tekel vd. (2016)'ne göre, görsel algının geliştirilmesini sağlayan tasarım eğitimi yaşamsal bir önem arz etmektedir. Öğrencinin kimliğini oluşturan formasyonu, bilgi ve sosyo-kültürel birikimi üzerine verilen eğitim, mesleğin tüm aşamalarında kullanılmaktadır. Eğitimin, öğrencinin bilgi ve algı seviyesini arttırması ve analiz-sentez yeteneği edindirmesi öngörülmektedir.

Bu makalede; tasarım odaklı düşünce ve yaratıcı düşüncenin oluşumunda öğrencinin kimliğinin eğitim sürecindeki rolü ve akademik performansıyla ilişkisi sorgulanmıştır. Öğrencinin eğitimi, aile yapısı, ilgi alanları ve geçmiş deneyimlerinin düşünce gelişimindeki ilişkisinin tespiti; tasarım eğitimi programlarının kurgulanmasına katkı yapması yanı sıra, eğitim plan ve metodolojisinin yeniden tasarımı ve sonrasında uygulanabilirliğinin arttırılması açısından önemlidir.

Süleyman Demirel Üniversitesi Şehir ve Bölge Planlama Bölümü temel tasarım dersi örneklemi üzerinden yapılan araştırmada; öğrencilerin bölüm tercihi ve gerekçeleri, öğrenci kültürel birikimi, öğrenci ve ebeveyn formasyonu ve mesleki profili gibi tasarım odaklı düşünce ve yaratıcı düşünce gelişimine dair faktörler kategorize edilmiștir. Ankete verilen cevaplar, akademik performanslar ve gözlemler her iki grupta aynı veya uyumludur.

Öğrencilerin üniversite sınavı başarı seviyesi akademik başarısını belirlemektedir. Bölüm tercihi ve gerekçeleri kategorisi kapsamında ilk kez Şehir Planlama bölümüne kayıt olan ve Anadolu Lisesi kökenli öğrencilerin bir kısmı Mimarlık bölümünü istemiş; kazanamadığından Planlama bölümüne kayıt olmuştur. Tercih gerekçeleri arasında tasarım odaklı düşünce ve yaratıcı düşünceyi öğrenme de vardır. Anket bulgularına göre, bilinçli olarak bölümü tercih edenlerin oranı evrenin yarısına yakındır. Derste başarılı olan öğrencilerin çoğunluğu bölüme isteyerek gelmiştir. Ancak bölüm seçiminde öğrencinin istekli olması veya sayısal puanla seçilerek gelmesi, yaratıcı düşünü oluşturabildiği anlamına gelme- mektedir. Öğrenme isteği bulunmayan öğrenciler de mevcuttur.

Öğrencilerin, çoktan seçmeli sınav mantığına ve tasarım odaklı düşünce ve yaratıcı düşünce oluşumu sürecindeki çeşitli nedenlere bağlı olarak performans düşüklüğü yaşadıkları gözlemlenmiştir. Bunlardan ilki, öğrencinin YKS başarı sırasına göre, en üst puan alan öğrenci ile en düşük puan alan öğrenci arasında puan farkının fazla olması ve iyi üniversitelere göre daha yüksek dilimlerde bölüme öğrenci alınmasıdır. Sınavındaki başarı düşüklüğü; algı, anlama ve düşünce gelişimindeki akademik performansın düşüklüğünün de nedenidir.

Baytin (2000:50)' in mimarlık öğrencilerinin dersi biraz anladıkları veya anlamada zorlandıkları yönündeki tespiti şehir planlama öğrencileri içinde geçerlidir. Dolayısıyla, eğitim sürecinde, tasarım pratiğinde gerekli olan beş tasarım faaliyetini gerçekleştirebilme becerisi öğrencilerin çoğu tarafından kazanılamamakta; tasarım muhakemesi oluşturma yönünde bir istem ise, bulunmamaktadır. Anket cevaplarının verilme biçimi bu konularda iz verse de, öğrenci becerileri konusunda ileri araştırma yapılması gerekmektedir.

Alg1 düzeyindeki düşüklüğün nedeninin; ortaöğretim sisteminin öğrencileri test mantığına sevk etmesi ve cep telefonu ve oyun bağımlılığı kaynaklı olduğu düşünülmektedir. Belirtilen olgular, eğitim planı dışı, ancak sonuç ürüne etki eder niteliktedir ve bağımlılık süreçte kırılamamaktadır. Öğrencinin sosyal medyadan uzaklaştırılması ve ilgisini derse verebilmesi için ek tedbirler alınmaktadır. İleri araştırma yapılması gerekli olan sanal dünyaya ve oyunlara bağımlılık konusunun; tasarım odaklı düşünce, yaratıcı düşünce ve görsel algı becerisinin oluşmasını zorlaştıran bir faktör olduğu değerlendirilmektedir.

Ankette oyun oynamadığını belirten öğrencilerin eğitim sürecinde oyun bağımlısı oldukları gözlemlenmiştir. Bilgisayar oyunlarının yaratıcılığın gelişimini engellediği savı mevcut bulgular üzerinden zemin bulamasa da, akademik performansı etkilediği açıktır. Algı seviyesinin oyunlarla bağlantısı ve öğrencinin sanal dünyaya 
erişim kabiliyetinin yaratıcı düşünce oluşumuna katkısı konularında ileri araştırma ihtiyacı belirgindir. Oyunların yüksek hayal gücü kurgularına rağmen, oyun oynayan öğrencilerin hayal gücü düşüklüğü vurgulanmalıdır.

Anaokulu eğitimi ve aile ilgisinin hayalgücüyle ilişkisi, çalışılmış ve ispatlanmış bir alandır. Ancak üniversite akademik performanslarına dair anaokulu bağlantılı çalışmalar kısıtlıdır. Bu araştırmada, anaokulu eğitimi alan bireylerin yaratıc düşünü kolay geliştirmesine ilişkin yoruma esas veri yetersiz kalmıştır. Tek belirgin olan bulgu, öğrencinin hayal gücünün eksikliğidir.

Öğrencinin tasarım muhakemesinin ve görsel alg1 becerilerinin gelişiminde gözel-zihin işbirliğini sağlamak açısından gerekli olan sosyo-kültürel birikim düzeyi düşüktür. Öğrencilerin önemli bir kısmının kültürel etkinliklere katılımı yoktur. Televizyon ve kitap alışkanlığı olan öğrenciler haber izlememektedir. Ayrıca, akademik performansı düşük öğrenciler; görsel sanatlar, sanat tarihi, arkeoloji disiplin alanlarına karşı isteksiz ve görsel ilişki kurmada eksiktir. Tekel vd. (2016)'nin görsel sanatlara ilgi ve deneyimi olan öğrencilerin görsel alg1 ve ifade gelişim süreçlerinin daha olumlu olduğu ve temel tasarım eğitimi ile görsel algının geliştirilebileceği yönündeki tespiti incelemeye konu örnek içinde geçerlidir. Farklı kentlere gidilmesi ve kentlere seyahat ile kişiliğin gelişimi ve akademik performans ilişkisi ise, tespit edilememiştir.

Evren, temel tasarım eğitimi olmayan, aile ve bireysel profili düşük ve çoktan seçmeli eğitimle formatlanmış düşünce yapısına, belirli bir üniversite başarı puanına ve benzer formasyona sahip olan öğrencilerden oluşmaktadır. Temel tasarım eğitimi sonundaki akademik performanslar; öğrencilerin tasarım öğretisini tam veya eksiksiz öğrenemediğini ve görsel algının gelişimini sağlayamadığını göstermektedir.

Öğrencinin akademik başarısının belirleyicisi etmenlerden bir diğeri; ebeveynin formasyonu ve mesleki profilidir. Anne ve babaların meslek profilleri; genelde arti- zanal, tarımsal ve işgücüne bağlı faaliyet alanlarındadır. Ağırlıklı olarak ilkokul ve ortaokul mezunu olan annelerin çoğunluğu evhanımı ve babaları, özel sektör çalışanı veya serbest meslek erbabıdır. Öğrencinin akademik başarısının Nelson (2009)'un belirttiği babanın formasyonu ve meslek profili ile doğrudan iliş̧kisi bu araştırma için de geçerlidir. Akademik başarı gösteren öğrencilerin babası yüksek eğitim ve meslek profili sahibidir.

Analitik ve eleştirel düşünce gelișimi, tasarım odaklı düșünce ve yaratıcı düșüncenin oluşumundaki temel faktördür. Gelișiminde sorun yaşayan öğrenciler anketi doldururken düşünce ve muhakeme geliştirmede zorlanacaklarını belirtmişlerdir. Öğrenciler matematiksel veya istatistiksel hesaplara ilgi duymadıklarını; karışık problemleri çözerken sıkıldıklarını; sayısal bulmacaları çözmenin hoşlarına gitmediğini; problem çözme konusunda formüller bulamadıklarını ve konulara sistematik yaklaşamadıklarını ifade etmişlerdir. Sorulara olumsuz cevap verenlerin çoğunluğu dersten kalmış veya düşük not almıştır. Konulara sistematik yaklaşım yapmadığını belirten öğrencilerin ders sonunda geçer not alması, sistematik düşüncenin geliştiğinin tek göstergesidir.

Öğrencilerin kimliği; eğitim ve sosyo-kültürel boyutuyla birlikte, yaratıcı düşünceyi anlama, algılama, oluşturma ve aktarmada etkendir. Temel tasarım eğitiminin kültürel birikimi ve formasyonu düşük öğrencilere verilmesinin zor olduğu değerlendirilmektedir. Söz konusu tespit, örnekleme yakın sıralamadaki üniversiteler ile yüksek puan1 șehir planlama bölümleri için benzer bir inceleme yapıldıktan sonra genellenebilir.

Temel tasarım derslerinde artan oranda bilgisayar teknolojilerinin kullanımı veya bilgisayar destekli eğitim metodolojisi içeren melez eğitim yöntemleri uygulanmaktadır. Covid-19 Pandemisi'nin etkisiyle, Acar (2020) ve Khogali (2020)'nin de belirttiği üzere, önümüzdeki dönemde uzaktan eğitim tasarım eğitiminde önemini hissettiren bir konu olacaktır. Ancak, Sarıoğlu Erdoğdu (2016)'nun vurguladığı gibi, Gestalt kuramının geliştirdiği ilkeler 
ve tasarım kavramları ile şekillenen bir temel tasarım eğitimi, mimarlık, planlama ve tasarım temel alanı disiplinleri için güncelliğini koruyacaktır.

Hangi yöntemle tasarım eğitimi verilirse verilsin, öğrencinin kültürel birikimi ile formasyonu, tasarım odaklı düşünce ve yaratıcı düşüncenin oluşumunda ve akademik performansında belirleyici olacaktır. Tasarım okullarına belirli dilimler dışında öğrenci alınmaması ve anne baba formasyonuna göre bölümlere öğrenci kabulü birer seçenektir. Ayrıca, Tekel vd. (2016)'nin, temel tasarım eğitiminde; öğrencide, görsel algının geliştirilmesi, yaratıcılığın desteklenmesi için orta öğretim programlarında; görsel sanatlar eğitimi ile birlikte temel tasarım eğitimine de yer verilmesi önermesi, yerinde bir tespit olarak değerlendirilmektedir. Söz konusu eğitim, öğrencinin alg1 seviyesini yükseltecek ve matematik geometri bilgisini güçlendirecek bir eğitim olmalıdır.

Bugün için bölüme öğrenci seçimi aşamasında; eğitmenlerin, öğrencileri seçmeveya orta öğretimde bu yönde müfredat geliştirilmesinde müdahale imkânı yoktur. Öğrencinin temel tasarımı öğrenme aşamasındaki düşünce oluşumu ve görsel alg1 becerisini geliştirmedeki başarısızlığının mesleki üretimlerinin hatalı, eksik veya yetersiz olmasına neden olacağı açıktır. Bu nedenle, öğrencinin; öğrenme, anlama, ilişki kurma, hayal etme ve tasar oluşturma yetisi geliştirmesinde, kültürel birikim ve formasyonunun etkisi eğitim metodolojisi, program ve planının tasarımı aşamasında dikkate alınmalıdır

\section{Teşekkür ve Bilgi Notu}

Prof. Dr. Nilgün GÖRER TAMER'e ve hakemlerimize katkılarından ve Bernard KENNEDY'ye İngilizce düzeltmelerinden dolayı teşekkür ederim. Makalede; ulusal ve uluslararası araştırma ve yayın etiğine uyulmuştur. Etik Kurul izni gerekmemiştir.

\section{Kaynakça}

Acar, A. (2020). Acil Uzaktan Eğitim Döneminde Mimarlık Birinci Sınıf Eğitimi Değerlendirmeleri. Arkitera.

Al-sagrat, K.A.A. ve Abu As'ad, A.A. (2015). Influence of Kindergarten Curriculum on the Development of Creative Thinking Skills and Self-Efficacy among Kindergartens. International Journal of Education. 7(1).

Arkun, N. S, Kaya, İ.S., Önbilgin, T.T., Sayar, Y., Arıtan, Ö., Atılgan, D. ve Öcal, V. C. (2000). Mimar Adaylarına Temel Tasarım Eğitiminde Uygulanan Bir Program Üzerine Düşünceler..., Mimarlık, Dosya: Temel Tasarım Eğitimi. 293, 9-40.

Arnheim, R. (1965) "Visual Thinking." Education of Vision (Ed.) Gyorgy Kepes. New York: George Braziller, $1-15$

Atmaca, A. E. (2014). Temel Tasarım. Nobel Yayınları.

Avnet, M. Makara, D., Larwin, K.H. ve Erickson, M. 2019. The impact of parental involvement and education on academic achievement in elementary school. International Journal of Evaluation and Research in Education (IJERE), 8(3), September 2019, pp. 476 483 ISSN: 2252-8822.

Aydın, B. (2001). Bireysel Özgürlük ve Erdem. H. Ayhan, O. Oğuz, A. Oktay (Eds.), 21. Yüzyılda Eğitim ve Türk Eğitim Sistemi. İstanbul: Sedar Yayıncılık, 95-110.

Ayıran, N. (1985). Yaratıcılık Açısından Mimarlık Eğitiminde Problemler, Mimarlık. 23(8), 16-17.

Bayraktar, B., Görer Tamer, N., Tekel, A. Gürer, N. Ceylan Kızıltaş, A. ve Aratlı Köroğlu, B. (2012). Görsel Eğitimde Yaratıcılık ve Temel Tasarım. Ankara: Nobel Yayınları.

Baytin, Ç. (2000). "Mimari Anlatım” Anlatım İçin Yeterli mi? Mimarlık, Dosya: Temel Tasarım Eğitimi. 293, 49-50.

Bertolini, R. ve Nissim, S. (2002). Video Games and Children's Imagination. Journal of Child Psychotherapy, Vol: 28(3). December.

Blanco-Herrera, J.A. (2017). Video Mining Creativity: Video Game Creativity Learning Effects. Iowa State University Digital Repository. Master thesis.

Broadbent, G. ve Ward, A. (1969). Design Methods in Architecture. New York, G. Wittenborn.

Craft, A. (2002). Creativity and Early Creativity and Early Years Education. A Lifewide Foundation. London: Continuum.

Çağlar, A. (2002). 21. Yüzyılda Okulun Değişen Rolüve Yeni Eğilimlere İlişkin İyimser Bazl Öngörüler, H. Ayhan, O. Oğuz, A. Oktay (Eds.), 21. Yüzyılda Eğitim ve Türk Eğitim Sistemi. 81-94. İstanbul: Sedar Yayıncılik

Çubukçu, E. ve Gökçen Dündar, Ş. (2007). Can creativity be taught? An empirical study on benefits of visual analogy in basic design education, ITU AZ, 4(2), 67-80.

Darko-Adjei, N. (2019). The Use and Effect of Smartphones in Students' Learning Activities: Evidence from the University of Ghana, Legon. Library Philosophy and Practice (e-journal). 2851, 1-37.

Denel, B. (1979). A Method for Basic Design. Ankara: METU Faculty of Architecture. Publication No.31.

Denel, B. (1981). Temel Tasarım ve Yaratıcılık, ODTÜ Mimarlık Fakültesi Basım İşliği. Ankara.

Desforges, C. ve Abouchaar, A. (2003). The Impact of Parental Involvement, Parental Support and 
Family Education on Pupil Achievements and Adjustment: A Literature Review, Research Report RR433. Department for Education and Skills.

Dorst, K. (2011). The core of "design thinking" and its application. Design Studies, 32, 521-532.

Dorst, K. (2015). Frame innovation: Create new thinking by design. Cambridge: MIT Press.1-11.

Dorst, K. (2018). Mixing Practices to Create Transdisciplinary Innovation: A Design-Based Approach, Technology Innovation Management Review. August, 8(8), 61-65.

Er Bıyıklı, N. ve Gülen, L. A. (2018). Hayal Gücü ve Yaratıcılık Kavramlarının Tasarım Sürecine Etkisi. Idil Dergisi. 7 (50), 1273-1277.

Erkman, V. (1982). Mimari Tasarım İçin Bir Veri Üretim Yöntemi Olarak Cevre Analizi, İ.T.Ü Matbaası, İstanbul.

Gouwy, K. (2013). Reculer Pour Mieux Sauter: How to Extract Knowledge from the Past, Chapter Seventeen. MIMED Forum IV: Flexibility in Architectural Education, Beyhan Bolak Hisarligil, Sevgi Lokce and Oktay Turan (Eds.) Cambridge Scholars Publishing. 247-261

Greh, D. (1984). Art Education in the Third Wave. Art Education. March, 40-41.

Grigg, R. ve Lewis, H. (2019). Teaching Creative and Critical Thinking in Schools. London: SAGE Publications.

Günay, B. (2007). Gestalt Theory and City Planning Education, METU JFA, 2007/1 24(1), 93-113.

Hunt, J. W. (1987). Visual Literacy: Art as A Basic in the Elementary School Curriculum. Ph.D. Thesis.

Kaptan, B. H. B., Kaptan, Ö., Keleşoğlu, B. ve Tran, G. (2019). Bilgisayar Destekli Temel Tasarım. Buğru Han Burak Kaptan (Eds.). Anadolu Üniversitesi Yayını.

Karasar, N. (1994). Arastırmada Rapor Hazırlama. (7. baskı), Ankara: 3A Araştırma Eğitim Danışmanlık Ltd.

Kavas, R. K., Erbaş, İ. ve Danacı, H. M. (2016). Mimarlık eğitiminde temel tasarımın kavranmasına yönelik olarak süprematist resim uzamının yeniden değerlendirilmesi. Journal of Human Sciences. 13(3), 5813-5825.

Kayın, E. (2000). Hayatı Yeniden Yorumlamaya Başlamak ve Mimarlık Birinci Sınıf Eğitimi, Mimarlık, Dosya: Temel Tasarım Eğitimi. 293, 37-39.

Khogali, H. A. M. (2020). The Effect of COVID-19 CORONA VIRUS on Sustainable Teaching and Learning in Architecture Engineering. Modern Applied Science, July. 1-15.

Kuloğlu, N. (2000). Bir Temel Eğitim Dersi Uygulaması ve Deneyimler, Mimarlık, Dosya: Temel Tasarım Eğitimi. 293, 44-48.

Lahiry, S., Choudhury, S., Chatterjee, S. ve Hazra, A. (2019). Impact of social media on academic performance and interpersonal relation: A cross-sectional study among students at a tertiary medical center in East India. JHEP, Journal of Education and Health Promotion. s.1-6. DOI: 10.4103/jehp.jehp_365_18

Lawson, B. ve Dorst, K. (2009). Design expertise. Oxford. England: Architectural Press.

Michalopoulou, A. (2014). Inquiry-based learning through the creative thinking and expression in early years education. Creative Education. 5(6), 377-385.
Natarajan, B., Kasozi, J.A., Chepete, P ve Arundhathi, T. (2016). Impact of Family Background and Study skills on the Academic Performance of Higher Education Students: The case of Botho University, International Journal of Multidisciplinary and Current Research. 4, 83-92.

Nelson, J.K. (2009). Impact of Parent Education on Student Success, Utah Valley University Research Report

Özcan, Z., Bayraktar, N., Görer, N. ve Tekel, A. (2003). Kente dair analitik bir çözümleme: Sokaklar 'ilk yıl şehir planlama atölyesi deneyimi'. Gazi Üniversitesi Mühdendislik Mimarlık Fakültesi Dergisi, 18(2), 17-30.

Sarığlu Erdoğdu, G.P. (2016). Temel Tasarım Eğitimi: Bir Ders Planı Örneği. Planlama. 26(1), 7-19.

Sausmarez, M. de. (1992). Basic Design: The Dynamics of Visual Form. London: The Herbert Press.

SDÜ Mimarlık Fakültesi (2020). Öğrenci İşleri Birimi verileri.

Seylan, A. (2019). Temel Tasarım. İstanbul: YEM Yayınları. 2. Bask1.

Silver, R. A. (1981). Developing Cognitive Skills Through Art. United States Department of Education. Educational Resources Information Center. ED 207674

Tekel A., Tamer-Görer, N., Memlük O., Kızıltaş-Ceylan A. (2015). Temel Tasarım Eğitiminde Öğrencilerin Görsel Alg1 Becerilerinin Gelişim Sürecinin Sorgulanması. Başkent Üniversitesi II. Sanat ve Tasarım Ĕ̌itimi Sempozyumu, Disiplinlerarası Tasarım, Ankara. 209-216.

Tekel, A., Tamer-Görer, N., Memlük, O., Gürer, N., Ceylan Kizıltas, A. (2016). Görsel Sanatlara İlisskin Kişisel İlgi ve Deneyimlerin Temel Tasarım Eğitimine Yansıması. Sanat ve Tasarım Dergisi, 17(1), 159-169.

Tekeli, İ. (2003). Ĕ̆itim Üzerine Düşünmek. Ankara: Türkiye Bilimler Akademisi Yayınları.

Toğrul, B. (2007). Okul öncesi Eğitimde Kullanılan Yöntem ve Teknikler. M. Sağlam (Ed.), Özel Öğretim Yöntemleri. Eskișehir Anadolu Üniversitesi Yayınlar1, 75-100.

Usta, G. K., Özdemir, İ. M., Kuloğlu, N., Ustaömeroğlu, A. A., Beşgen, A. ve Vural, S. (2000). Mimarlık Eğitiminde Temel Tasarımın Yeri. Mimarlık, Dosya: Temel Tasarım Eğitimi. 293, 41-43.

Ülger, K. (2015). Sanat Eğitiminin Düşünme Becerileri Üzerine Etkisi. Milli Eğitim Dergisi. Bahar. 135-147.

Y1ldırım, İ. (2019). Architecture/Design Education in the Light of Transdisciplinary Approaches. 6. Uluslararası Multidisipliner Calısmalar Kongresi. Tam Metin Bildiri Kitabı, Başak Özkendirci ve Özlem Sağıroğlu (Eds.). 26-27 Nisan 2019, Gaziantep. 113-123.

Wolff, R. J. (1965). Visual Intelligence in General Education, Education of Vision. (Ed.) Gyorgy Kepes. New York: George Braziller, 220-230.

\section{Internet Kaynaklart}

Doyle, A. (2019). What is Creative Thinking? https://www. thebalancecareers.com/ creative-thinking-definition-with-examples-2063744, Erișim tarihi: 10.01.2020.

Çetin, İ. (2012). Hayal kurma ve yaratıcılık. https://www. tavsiyeediyorum.com/makale 8875.htm, Erișim tarihi: 26.04 .2020

YÖK Atlas, 2018, 2019 verileri. https://yokatlas.yok.gov. 
tr/2019/lisans.php?y= 109210317 ve https://

yokatlas.yok.gov.tr/2018/lisans.php?y=109210317

Erişim tarihi: 14.08.2021.

Şehir ve Bölge Planlama 2018 Taban Puanları ve Başarı Siralamaları (ŞBP TPBS, 2018)

https://www.universitego.com/sehir-bolge-planlama-2018-taban-puanlari-basari-sirala malari/ Erişim tarihi: 14.08.2021.

Şehir ve Bölge Planlama Bölüm 2019 Taban Puanları ve Başarı Sıralaması (ŞBP TPBS, 2019) https://www. basarisiralamalari.com/sehir-ve-bolge-planlama-2019-taban-puanlari-ve-basari-siralamalari/ Erişim tarihi: 14.08.2021. 